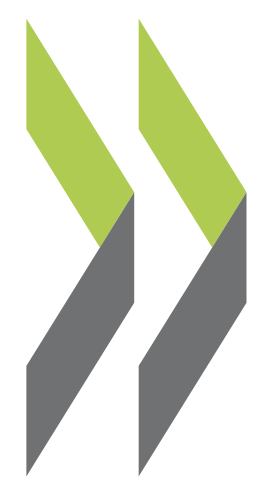

OECD Economics Department Working Papers No. 650

Reforming the Tax System in Japan to Promote Fiscal Sustainability and Economic Growth

\section{Randall S. Jones,}

Masahiko Tsutsumi 
Organisation de Coopération et de Développement Économiques

Organisation for Economic Co-operation and Development

01-Dec-2008

ECONOMICS DEPARTMENT

English - Or. English

REFORMING THE TAX SYSTEM IN JAPAN TO PROMOTE FISCAL SUSTAINABILITY AND ECONOMIC GROWTH

ECONOMICS DEPARTMENT WORKING PAPERS No. 650

By Randall S. Jones and Masahiko Tsutsumi

All OECD Economics Department Working Papers are available on the OECD Internet website at www.oecd.org/eco/working_papers 


\section{ABSTRACT/RÉSUMÉ}

\section{Reforming the tax system in Japan to promote fiscal sustainability and economic growth}

Tax reform is an urgent priority, as Japan needs as much as $5 \%$ to $6 \%$ of GDP of additional government revenue just to stabilise public debt, which has risen to $180 \%$ of GDP. In addition to raising revenue, tax reform should promote economic growth, address the deterioration in income distribution and improve the local tax system. Additional revenue should be obtained primarily by increasing the consumption tax rate, currently the lowest in the OECD area, while broadening the personal and corporate income tax bases. The corporate tax rate, now the highest in the OECD area, should be cut to promote growth, while eliminating aspects of the tax system which discourage labour supply and distort the allocation of capital. Japan should also consider introducing an Earned Income Tax Credit to promote equity. The local tax system should be simplified, increasing reliance on existing taxes on property, income and consumption.

This Working Paper relates to the 2008 OECD Economic Survey of Japan (www.oecd.org/eco/surveys/japan).

JEL classification: $\mathrm{H} 20 ; \mathrm{H} 22 ; \mathrm{H} 23 ; \mathrm{H} 24 ; \mathrm{H} 25$

Keywords: Taxation; tax reform; labour tax wedge; property taxes; consumption tax; personal income tax; corporate income tax; Japanese tax system; tax progressivity; tax expenditures; female labour force participation; earned income tax credit; local tax system.

\section{Réformer la fiscalité au Japon pour promouvoir la viabilité budgétaire et la croissance économique}

La réforme fiscale est une priorité urgente: l'État japonais doit se procurer des recettes supplémentaires à hauteur de 5 à $6 \%$ du PIB pour simplement stabiliser la dette du pays, qui atteint désormais $180 \%$ du PIB. Au-delà de cette progression des ressources, la réforme fiscale devrait promouvoir la croissance économique, faire face à la dispersion croissante de la distribution des revenus et améliorer la fiscalité locale. Les recettes supplémentaires devraient provenir pour l'essentiel d'une augmentation du taux de la taxe sur la consommation, qui est actuellement le plus faible de toute la zone OCDE, et de l'élargissement des bases d'imposition des revenus des personnes physiques et morales. Les autorités devraient abaisser le taux de l'impôt sur les sociétés, aujourd'hui le plus élevé des pays membres de l'OCDE, afin de promouvoir la croissance, et supprimer les mécanismes fiscaux qui sont préjudiciables à l'offre de main-d'œuvre et perturbent les affectations de capital. Le Japon devrait aussi envisager, pour favoriser l'équité, l'instauration d'un crédit d'impôt sur le revenu d'activités professionnelles. La fiscalité locale devrait bénéficier de mesures de simplification et s'appuyer davantage sur les impôts et taxes déjà en vigueur en matière foncière et immobilière, ainsi que sur les revenus et sur la consommation.

Ce Document de travail se rapporte à l'Étude économique de l'OCDE de Japon, 2008 (www.oecd.org/eco/etudes/japon).

Classification JEL : H20; H22; H23; H24; H25

Mots clés: Fiscalité; réforme de la taxation; taxe foncière; taxe à la consommation; impôt sur le revenu; impôt sur les profits; système de taxation japonais; progressivité de l'impôt; dépenses fiscales; l'activité des femmes; crédit d'impôt sur le revenu d'activités professionnelles; fiscalité locale.

\section{Copyright OECD 2008}

Application for permission to reproduce or translate all, or part of, this material should be made to: Head of Publications Service, OECD, 2 rue André-Pascal, 75775 Paris Cedex 16, France. 


\section{TABLE OF CONTENTS}

\section{REFORMING THE TAX SYSTEM IN JAPAN TO PROMOTE FISCAL SUSTAINABILITY AND}

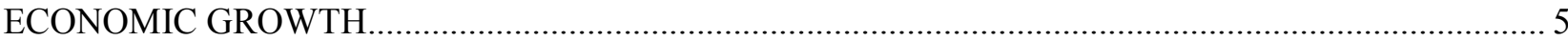

Major challenges facing the Japanese tax system ……..................................................................... 5

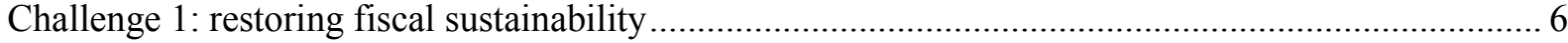

Challenge 2: supporting growth in the context of rapid population ageing and globalisation ............... 10

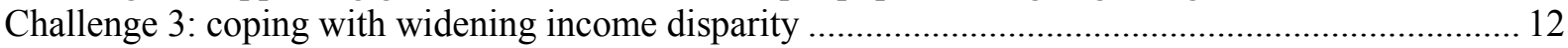

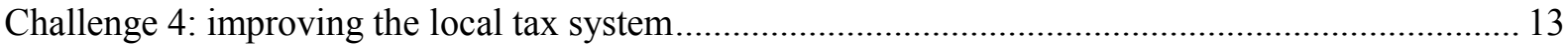

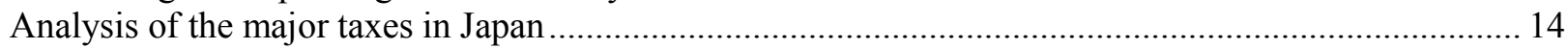

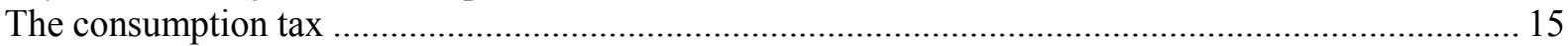

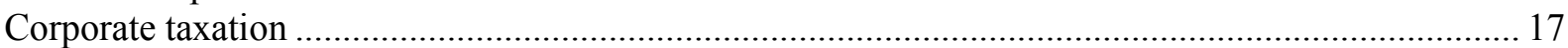

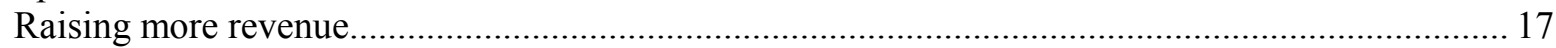

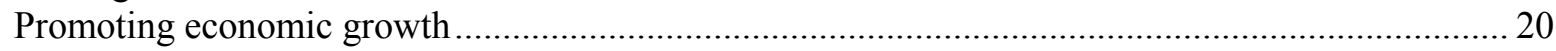

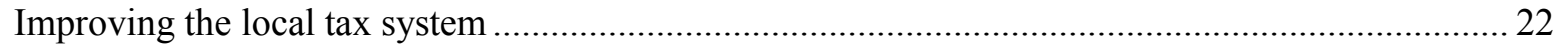

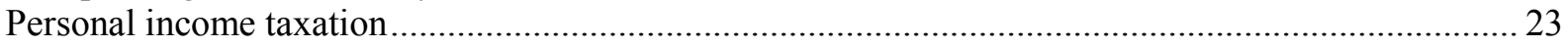

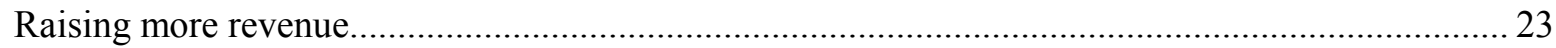

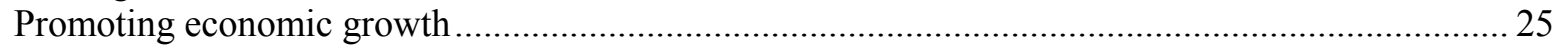

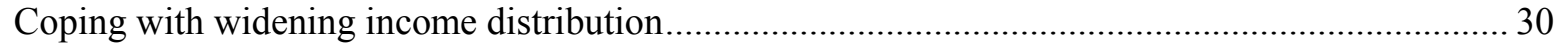

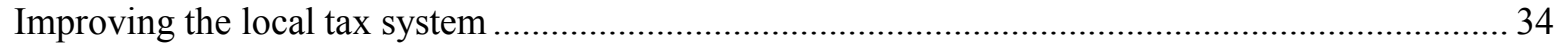

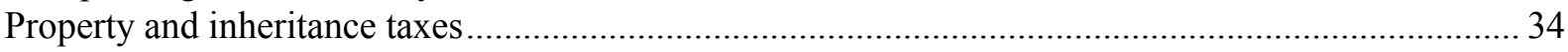

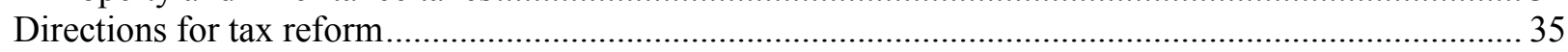

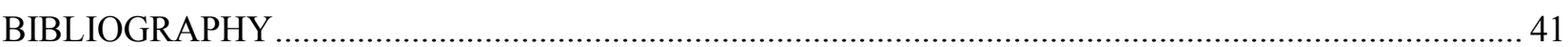

\section{Tables}

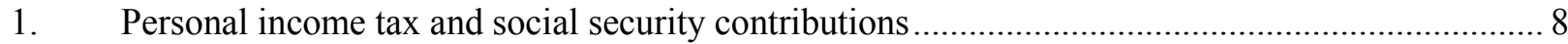

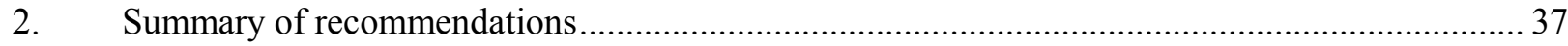

\section{Figures}

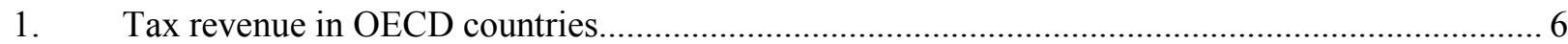

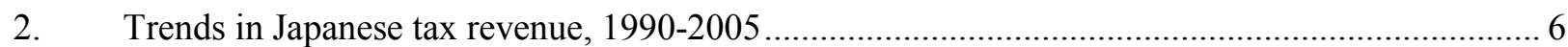

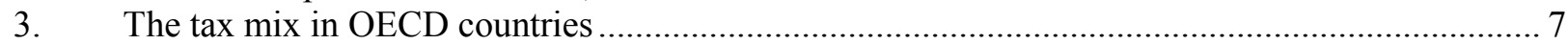

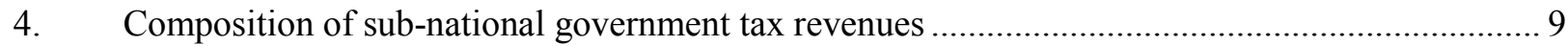

5. The impact of taxes and the social security system on income distribution in Japan .................. 12

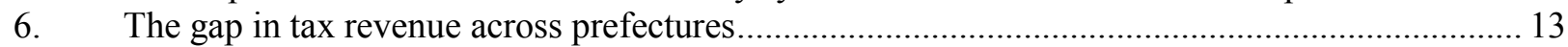

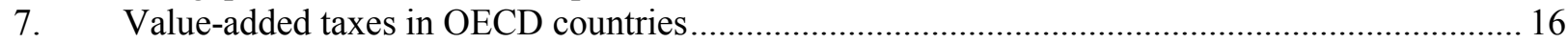

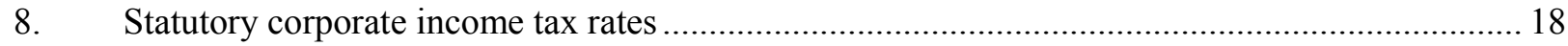

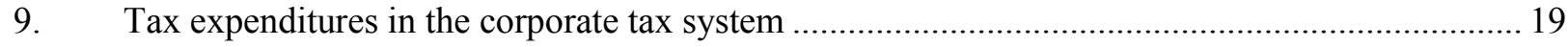

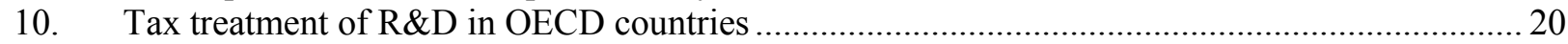

11. Proportion of firms making losses according to the national tax code........................................ 20

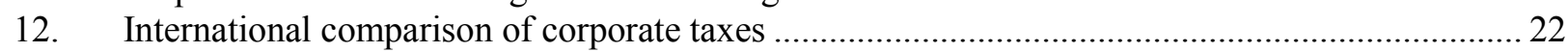




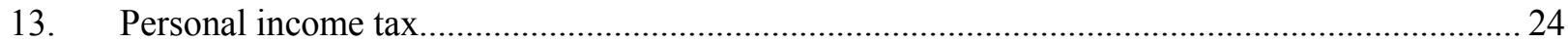

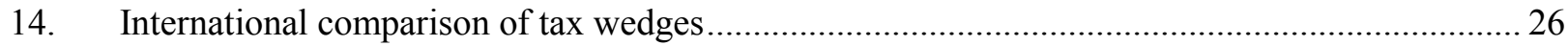

15. International comparison of labour force participation rates and part-time employment ............. 28

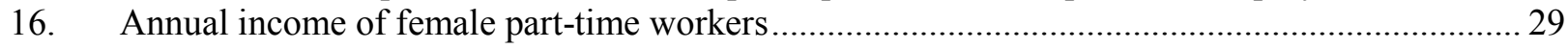

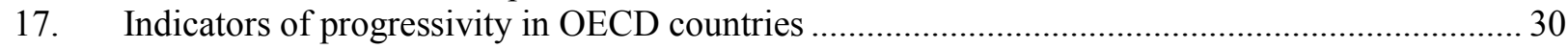

18. Tax and social security payments by income decile................................................................. 31

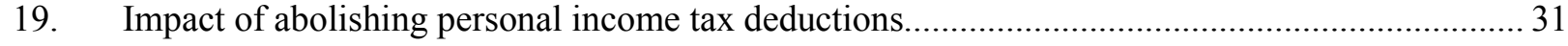

20. International comparison of immovable property taxes ............................................................ 35

\section{Boxes}

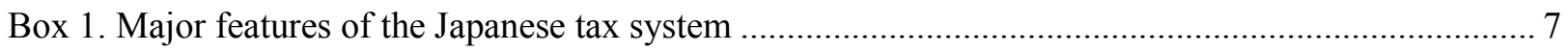

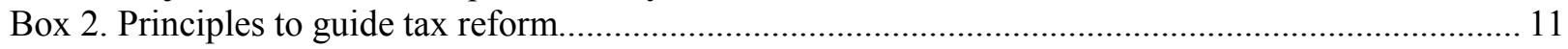

Box 3. Recent progress in tax reform in Japan: a follow-up of the 1999 Economic Survey of Japan ...... 14

Box 4. Earned Income Tax Credit systems in OECD countries........................................................... 32

Box 5. A comparison of the OECD recommendations with those of the Tax Commission .................... 39 
ECO/WKP(2008)58

\title{
REFORMING THE TAX SYSTEM IN JAPAN TO PROMOTE FISCAL SUSTAINABILITY AND ECONOMIC GROWTH
}

\author{
Randall S. Jones and Masahiko Tsutsumi ${ }^{1}$
}

1. The Japanese tax system is facing one of the most difficult and complicated challenges of any OECD country: raising tax revenue to stem the steep run-up in public debt and finance higher social spending resulting from rapid population ageing, while also promoting economic growth, addressing the deterioration in income distribution and increasing the gains from fiscal decentralisation. There is much scope for raising additional tax revenue in Japan, in particular by raising the consumption tax rate, which is the lowest among OECD countries at 5\%, and by broadening the base of direct taxes. Given the increasing urgency of the fiscal situation, the government's medium-term fiscal plan calls for a "fundamental reform of the tax system". While raising additional tax revenue is important, the already low potential growth rate and declining labour force reinforce the need for tax reform to enhance productivity and output growth. In addition, the tax system should address the problem of widening income inequality and rising relative poverty, while reforms in local government taxes are needed to increase the gains from decentralisation.

2. This paper begins by presenting the key challenges facing the Japanese tax system - raising the necessary revenue, supporting economic growth, reversing the increase in inequality and improving fiscal relations between central and local governments. The following section analyses the major tax issues from the perspective of meeting these challenges. The paper concludes with recommendations for a comprehensive tax reform, which are summarised in Table 2.

\section{Major challenges facing the Japanese tax system}

3. Japan's tax system stands out among OECD countries in a number of ways (see Box 1). First, the ratio of total tax revenue to GDP is one of the lowest in the OECD area (Figure 1). ${ }^{2}$ Second, the reliance on direct taxes - personal and corporate income taxes and social security contributions - is relatively high compared to other OECD countries. Third, the local tax system is exceptionally complicated. Given these features of Japan's tax system, resolving the challenges outlined below will require a major overhaul of the system.

1. Randall S. Jones is head of the Japan/Korea Desk in the Economics Department of the OECD and Masahiko Tsutsumi is an economist on that desk. This paper is based largely on material from the $O E C D$ Economic Survey of Japan published in April 2008 under the authority of the Economic and Development Review Committee (EDRC). The authors would like to thank Andrew Dean, Christopher Heady, Val Koromzay, Stefano Scarpetta and Taesik Yoon for valuable comments on earlier drafts. Special thanks go to Lutécia Daniel for technical assistance and to Nadine Dufour for technical preparation.

2. Excluding social security, tax payments in Japan in 2005 were the lowest in the OECD area after Mexico at $17.3 \%$ of GDP. 
Figure 1. Tax revenue in OECD countries Per cent of GDP in 2005

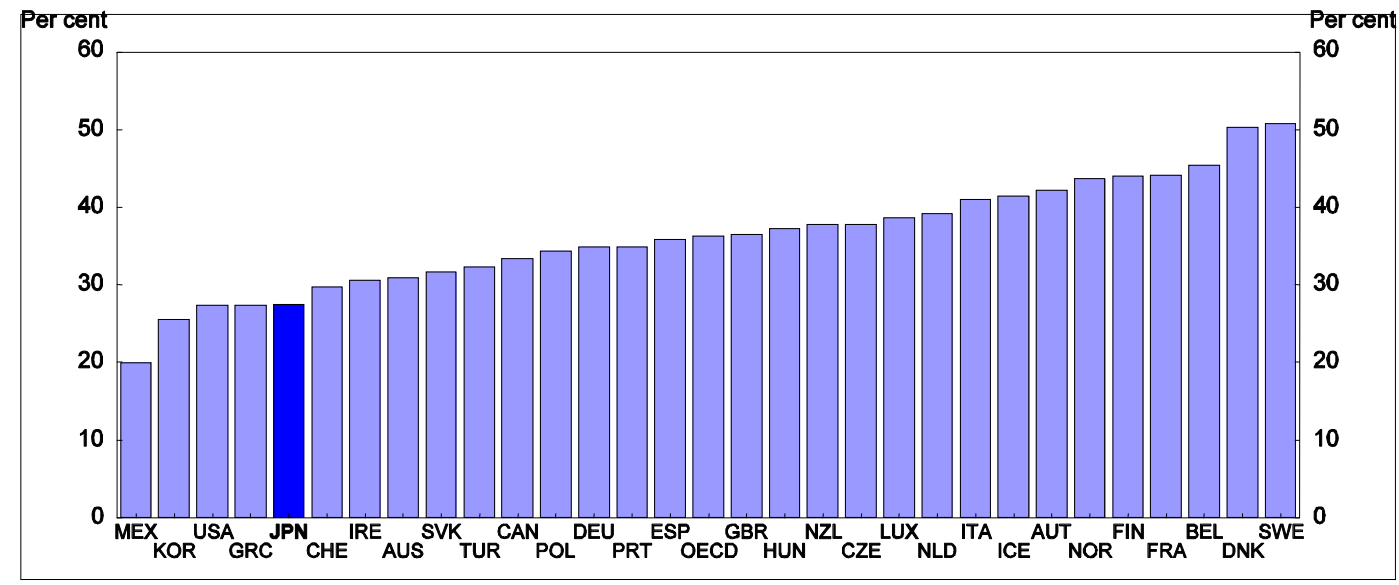

Source: OECD (2007), Revenue Statistics 1965-2006, OECD, Paris (http://dx.doi.org/10.1787/366725334503).

\section{Challenge 1: restoring fiscal sustainability}

4. The counter-cyclical fiscal policies implemented to support economic growth following the collapse of the bubble economy in the early 1990s resulted in unsustainably high budget deficits and a runup in government debt. On the expenditure side, an increase in public investment and social security outlays boosted government spending. On the revenue side, the government introduced a series of tax cuts that were partially offset by a hike in the consumption tax rate in 1997. Tax revenue fell from a peak of $30 \%$ of GDP in 1990 to $26 \%$ in 2003 , before rebounding slightly with the economic expansion (Figure 2). The fall in revenue since 1990 is explained by a 5 percentage-point decline in direct taxes on households and firms (as a share of GDP), which more than offset a 2.5 percentage-point rise in social security contributions. Overall, the decline in revenue accounted for almost a quarter of the increase in the fiscal deficit between 1990 and 2005. Although the deficit has been on a decreasing trend since its peak of $8 \%$ in 2002 , the accumulated amount of debt, at $180 \%$ of GDP in gross terms, makes the fiscal situation vulnerable to interest rate fluctuations. The need for additional revenue is illustrated by the fact that bond issuance accounts for $30 \%$ of general account revenues, about half of the $60 \%$ share of tax revenue.

Figure 2. Trends in Japanese tax revenue, 1990-2005

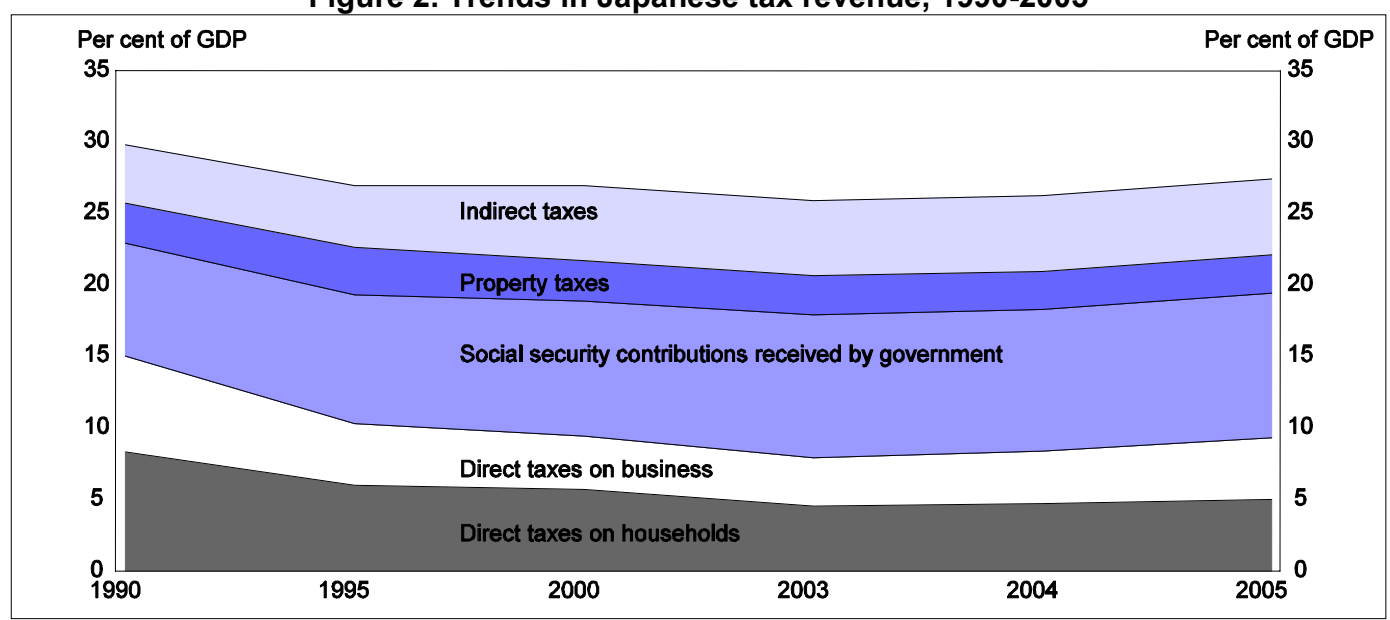

Source: OECD (2007c), Revenue Statistics 1965-2006, OECD, Paris (http://dx.doi.org/10.1787/366725334503). 
5. The task of restoring fiscal health is complicated by a number of factors, notably the unprecedented speed of ageing. Indeed, the share of the population over age 65 increased from $7 \%$ in 1970 to $20 \%$ in 2006 (2008 OECD Economic Survey of Japan). In contrast, a similar transition is projected to take at least 80 years in the other major industrialised countries. As a share of the working-age population (aged 20 to 64), the over 65 age group is projected to rise from $28 \%$ in 2000 to $72 \%$ in 2050 , the second highest in the OECD area.

\section{Box 1. Major features of the Japanese tax system}

\section{National taxes}

At $18 \%$ of total tax revenue, direct taxes on households are below the OECD average of $25 \%$ (Figure 3 ). The four rates in the personal income tax system in FY 2006 - ranging from 10\% to 37\% - were replaced by six rates from $5 \%$ to $40 \%$ in FY 2007 (Table 1). However, this was offset by changing the inhabitant tax (a local government tax) from three rates to a single rate of $10 \%$. Consequently, the combined tax rate on household income - personal income tax plus the local inhabitant tax - still ranges from $15 \%$ to $50 \%$ and the rates are identical to the FY 2006 level for most income categories. Nearly $60 \%$ of taxpayers fall into the lowest tax rate and the top rate starts at 3.6 times the average wage, compared to an average of 2.4 times in the OECD area. Given that less than half of wage income is subject to the personal income tax (see below), a worker would have to earn more than seven times the average wage to be subject to the $50 \%$ rate. Consequently, less than $1 \%$ of taxpayers fall into the $50 \%$ tax rate, which is high by international standards, while $3 \%$ are in the $43 \%$ rate. About a quarter of salaried employees do not pay any personal income tax. Retirement income receives preferential treatment, as it is reduced by a special deduction for older persons and then only half of the remaining income is taxed. Financial income, including interest, dividends and capital gains, is taxed separately at a $20 \%$ rate. However, in an effort to boost the stock market, the rate has been temporarily reduced to $10 \%$ on dividends (until the end of March 2009) and on capital gains on listed stocks and equity investment trusts (until the end of December 2008). Capital gains from the sale or transfer of land, buildings, and securities are also taxed separately. Capital gains on real estate are taxed at $39 \%$ for short-term gains (when the property is held less than five years) and $20 \%$ for long-term gains.

Figure 3. The tax mix in OECD countries

Per cent of total tax revenue in $2005^{1}$

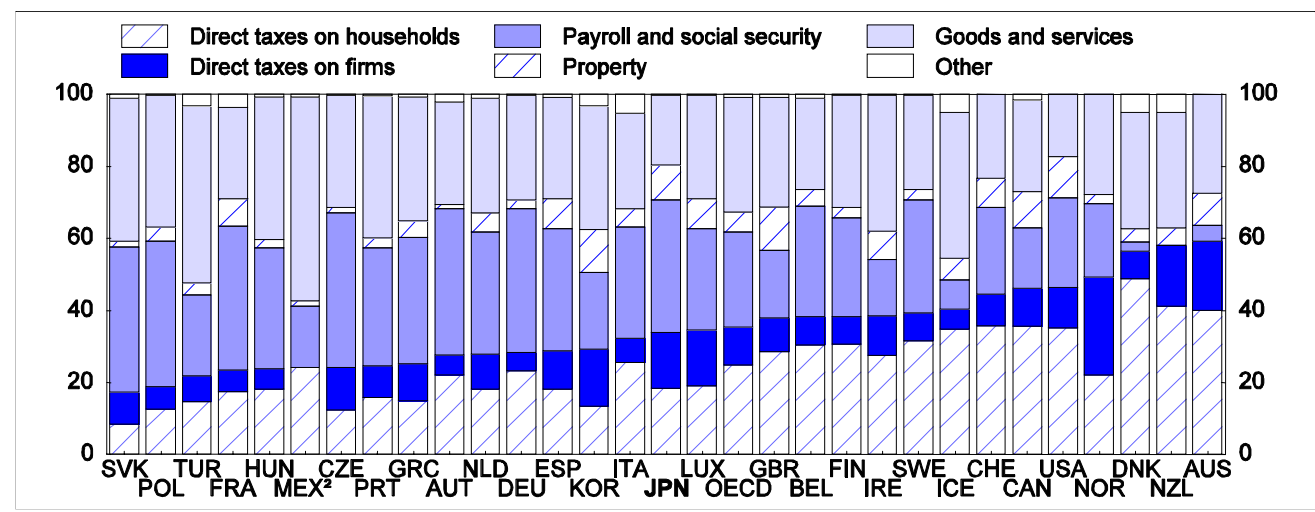

1. Countries are ranked by the share of direct taxes on households and firms in total taxes.

2. For Mexico, the data for direct taxes on households also contains direct taxes on firms.

Source: OECD (2007c), Revenue Statistics 1965-2006, OECD, Paris (http://dx.doi.org/10.1787/366725334503).

Direct taxes on households fell from 8\% of GDP in 1990 to 5\% in 2005 (Figure 2). A salaried employee with a wife and two children earning the average salary of around 5 million yen ( $\$ 46000)$ per year paid an average tax rate of $4.0 \%$ in 2007 compared to $7.8 \%$ in 1986 (Ministry of Finance, 2007). For a salary of 30 million yen, the rate declined from $45 \%$ to $30.6 \%$ over that period. The relatively low effective income tax reflects generous allowances and deductions, notably for wage income. The wage deduction is 0.65 million yen on wages of up to 1.63 million yen and rises with income, though at a diminishing rate. ${ }^{1}$ There are a number of other exemptions and deductions, including those for spouses and dependent relatives, widows, the handicapped, working students, social insurance payments, premiums for life and casualty insurance, casualty losses and medical expenses, in addition to the basic exemption for all taxpayers. These deductions and exemptions add up to more than half of wage earnings. 
Table 1. Personal income tax and social security contributions

A. Personal income

\begin{tabular}{|c|c|c|c|c|c|c|c|c|}
\hline \multicolumn{3}{|c|}{ Income tax } & \multicolumn{3}{|c|}{ Local inhabitant tax } & \multicolumn{3}{|c|}{ Total } \\
\hline $\begin{array}{c}\text { Taxable income } \\
\text { (million yen) }\end{array}$ & $\begin{array}{c}2007 \\
(\%)\end{array}$ & $\begin{array}{c}2006 \\
(\%)\end{array}$ & $\begin{array}{c}\text { Taxable income } \\
\text { (million yen) }\end{array}$ & $\begin{array}{c}2007 \\
(\%)\end{array}$ & $\begin{array}{c}2006 \\
(\%)\end{array}$ & $\begin{array}{c}\text { Taxable income } \\
\text { (million yen) }\end{array}$ & $\begin{array}{c}2007 \\
(\%)\end{array}$ & $\begin{array}{c}2006 \\
(\%)\end{array}$ \\
\hline Under 1.95 & 5 & \multirow{3}{*}{10} & \multirow{3}{*}{ Under 2.0} & \multirow{8}{*}{10} & \multirow{3}{*}{5} & Under 1.95 & 15 & 15 \\
\hline \multirow[b]{2}{*}{ From 1.95 to 3.3} & \multirow[b]{2}{*}{10} & & & & & 1.95 to 2.0 & 20 & 15 \\
\hline & & & & & & 2.0 to 3.3 & 20 & 20 \\
\hline From 3.3 to 6.95 & 20 & \multirow{2}{*}{20} & \multirow{2}{*}{ From 2.0 to 7.0} & & \multirow{2}{*}{10} & 3.3 to 6.95 & 30 & 30 \\
\hline From 6.95 to 9.0 & 23 & & & & & 6.95 to 7.0 & 33 & 30 \\
\hline From 9.0 to 18.0 & 33 & 30 & \multirow{3}{*}{ From 7.0} & & \multirow{3}{*}{13} & 7.0 to 9.0 & 33 & 33 \\
\hline \multirow[t]{2}{*}{ Over 18.0} & \multirow[t]{2}{*}{40} & \multirow[t]{2}{*}{37} & & & & 9.0 to 18.0 & 43 & 43 \\
\hline & & & & & & Over 18.0 & 50 & 50 \\
\hline
\end{tabular}

B. Social security contributions (as of October 2007)

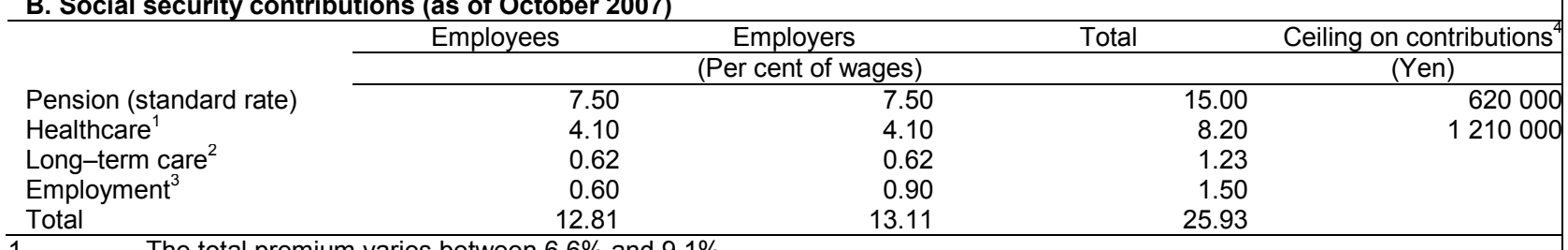

1. The total premium varies between $6.6 \%$ and $9.1 \%$.

2. The premium for long-term care is paid only by those between the ages of 40 and 65

3. The employment insurance contribution by employers includes a $0.3 \%$ charge for employment programmes.

4. Contributions are paid on monthly salaries up to this amount.

Source: Ministry of Finance and Ministry of Health, Labour and Welfare.

Revenue from the corporate income tax fell from $6.7 \%$ of GDP in 1990 to $3.7 \%$ in 2004, before rebounding to $4.3 \%$ in 2005 . It accounted for $15 \%$ of total tax revenue in 2005 , compared to the OECD average of $10 \%$. The tax rate varies by the size of capital and sales, with a lower rate granted to smaller companies. For corporations with capital of more than 100 million yen ( $\$ 914$ thousand), the central government tax rate is $30 \%$ (although local taxes boost the overall rate to $40 \%$, the highest in the OECD area). For corporations with capital below 100 million yen, the tax rate is $22 \%$ for income up to 8 million yen.

Mandatory social security contributions by employees and employers for pensions, heath, long-term care and unemployment are the single largest source of government revenue at $37 \%$ of the total in 2005 . Under the FY 2004 reform, the pension contribution rate is being raised from $13.6 \%$ in FY 2004 to $18.3 \%$ by FY 2017. Contributions are imposed on wages up to 0.62 million per month (1.5 times the average wage). Total social security contributions amount to $26 \%$ of wages, shared almost equally between employees and employers (Table 1, Panel B).

The consumption tax (a tax on value added) accounts for half of indirect tax revenue, which provides almost onefifth of total tax revenue. The consumption tax was introduced in 1989, with a $3 \%$ rate that was raised to $5 \%$ in 1997 . The rate is applied to all businesses with taxable sales of more than 10 million yen, although a simplified system for calculating the tax is available to businesses with taxable sales of up to 50 million yen. In addition, specific indirect taxes are applied to some goods and services, including liquor, tobacco, gasoline, coal, aviation fuel, LPG fuel, and registration and licenses.

\section{Local taxes ${ }^{2}$}

Japan has a relatively complex local tax system consisting of 13 major prefectural taxes and ten municipal taxes, which cover personal and corporate income, property and consumption (Figure 4). The complicated system results in some duplication and overlapping of tax bases. For example, corporate income is subject to municipal and prefectural inhabitant taxes and to the prefectural enterprise tax, in addition to the central government corporate tax. Some discretionary power has been given to local governments to set rates for a number of taxes, but it has so far failed to promote tax competition and fiscal discipline. Moreover, several local taxes include tax-sharing arrangements with the central government. For example, one percentage point of the $5 \%$ consumption tax is levied by prefectures. This revenue is collected by the central government and distributed among prefectures based on objective criteria. In general, local governments tend to take the basic tax system as given by the central government, while competing to provide ad hoc tax rebates for specific policy targets, such as attracting firms to industrial parks, and introducing local discretionary taxes, such as those on nuclear waste and hotel stays. 
Figure 4. Composition of sub-national government tax revenues 2005

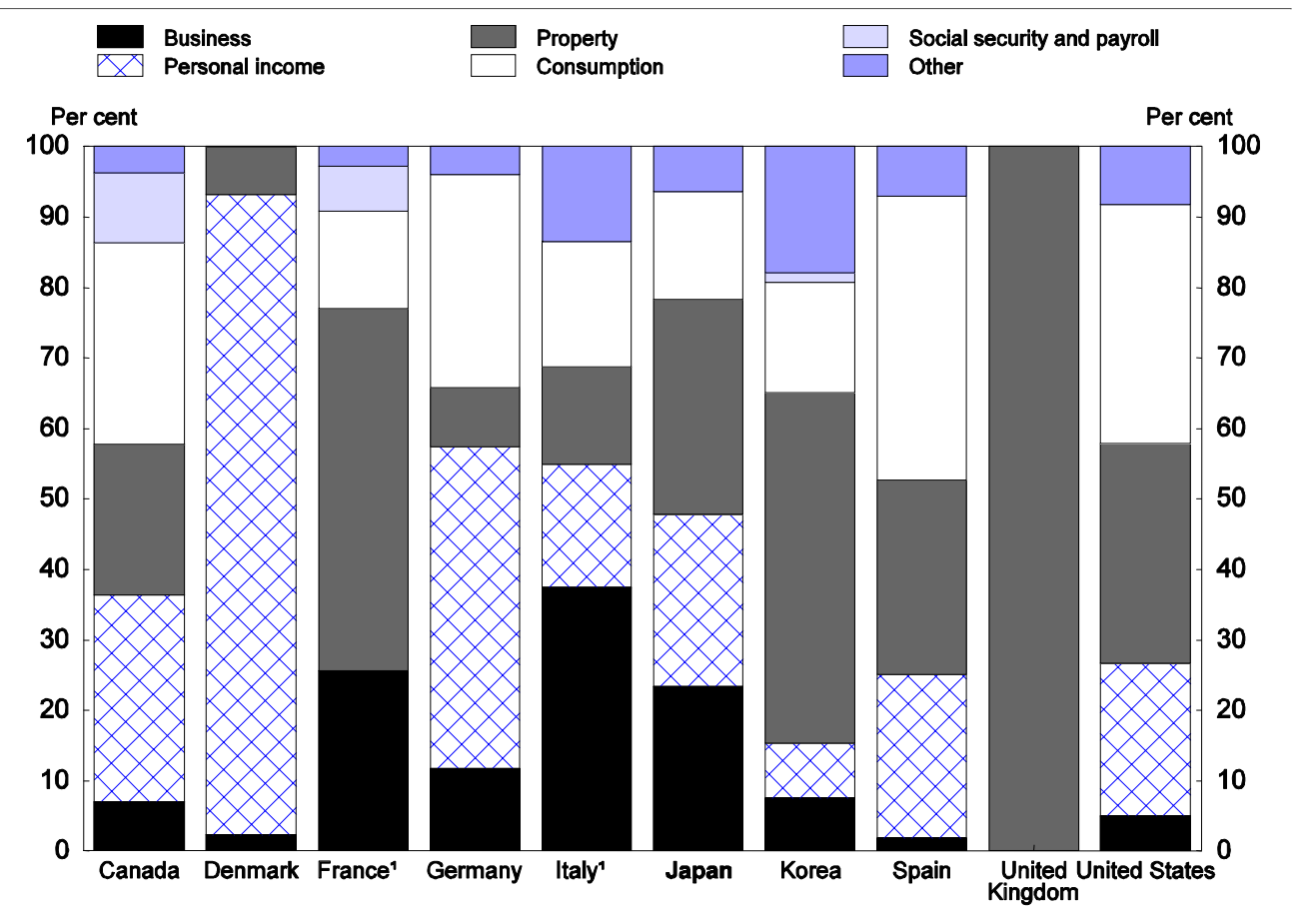

1. Including other taxes paid solely by business (Taxe professionnelle in France and IRAP in Italy).

Source: OECD (2007c), Revenue Statistics 1965-2006, OECD, Paris (http://dx.doi.org/10.1787/366725334503).

1. For example, employees are allowed to deduct $40 \%$ of annual wage income up to 1.8 million yen and $30 \%$ plus 180000 yen from wage income of 3.6 million yen. Thus, for a wage of 1.62 million yen, $40 \%$ is deducted from taxable income, but the ratio falls to $35 \%$ for wage income of 3.6 million yen.

2 See the 2005 OECD Economic Survey of Japan for a detailed description of local government taxes in Japan.

6. Ageing affects fiscal policy through its impact on both expenditures and revenues. On the expenditure side, the government plans to limit the rise in public social spending to $1 \%$ of GDP, from 17.5\% of GDP in 2006 to 18.4\% in 2015 (2008 OECD Economic Survey of Japan). Outlays are to be contained by measures to reduce pension benefits and encourage healthier lifestyles. However, achieving this target will be difficult, as the effectiveness of policies to contain healthcare spending is uncertain. ${ }^{3}$ On the revenue side, personal income tax receipts are likely to fall relative to GDP due to a decline in the share of the working-age population as well as a further erosion of the personal income tax base caused by the generous income deductions targeted at elderly people. It is estimated that demographic changes will reduce personal income tax revenue by $10 \%$ between 2000 and 2020, and by $40 \%$ between 2000 and 2050 under the current tax structure (Cabinet Office, 2002b). Rapid ageing thus implies that tax reform is needed simply to maintain the current amount of revenue.

3. An OECD study (OECD, 2006e) estimated that economic and demographic factors will boost public spending on healthcare and long-term nursing care from 7\% in 2005 to between $9 \%$ and $13 \%$ by 2050 . 
7. In the Direction and Strategy in 2007, the government set three targets to help restore fiscal sustainability; i) limiting the expansion in the size of the government; ii) a primary budget surplus in the combined central and local governments by FY 2011; and iii) a steady reduction in the debt to GDP ratio in the mid-2010s. Although the government's priority is on expenditure cuts, the plan also calls for fundamental reform of the tax system. The target of a primary balance surplus is just the first step towards restoring fiscal sustainability. According to a projection by the Cabinet Office and estimates by the OECD, an improvement of $4 \%$ to $5 \%$ of GDP in the primary budget balance is needed to stabilise the debt to GDP ratio. ${ }^{4}$ The same projection estimates that additional tax revenue, amounting to $4.6 \%$ to $5.9 \%$ of GDP, is needed to stabilise the debt ratio, assuming that growth is close to Japan's potential rate. Moreover, reducing the debt ratio requires an even larger primary budget surplus and thus a larger increase in tax revenue.

\section{Challenge 2: supporting growth in the context of rapid population ageing and globalisation}

8. The design of the tax system is crucial for output growth, as taxation impinges on most aspects of economic activity. A number of studies, including those by the OECD, suggest that the overall tax burden, and more importantly, a tax structure oriented toward direct taxes, can have a negative impact on growth. ${ }^{5}$ The effect thus depends on how tax increases are designed and implemented (Box 2), as well as on the use of the extra tax revenue. As noted, the composition of the tax burden influences growth; for a given level of taxes, a higher incidence of direct taxes relative to indirect taxes is detrimental to economic growth. Furthermore, for a given level of direct taxes, a higher proportion of corporate taxes relative to personal income taxes has an additional negative impact on growth. Designing a tax regime that limits the depressing impact of taxes on economic activity is particularly important in Japan, given the effect of rapid ageing on output growth. The decline in the working-age population is expected to keep Japan's potential growth rate at around $1 \frac{1}{2}$ per cent over the period $2008-13,{ }^{6}$ well below the OECD average of $2.1 \%$. With the increasingly negative contribution from a shrinking labour force, sustaining economic growth requires pro-growth tax reform, as well as reforms in a wide range of other areas to boost labour force participation, raise productivity and improve the allocation of resources (2008 OECD Economic Survey of Japan).

9. In addition, the tax system needs to adapt as globalisation strengthens the competitive pressure on firms, making them more sensitive to cross-country variations in the corporate tax system. The increasing mobility of resources across borders has prompted international competition to lower tax rates. Despite a cut in 1999, Japan has had the highest statutory corporate tax rate in the OECD area since 2006. Hence, it faces increasing pressure to keep up with international trends and maintain the country's growth potential by providing a tax framework that encourages firms and individuals to stay in Japan.

4. The Cabinet Office projection included two different assumptions for growth. Under the high-growth assumption of $2.4 \%$, the necessary improvement in the primary budget surplus is lower at $1.5 \%$ to $2.7 \%$ of GDP. However, such a growth rate is well above Japan's potential growth rate for the period 2007-11, which is estimated at $1.4 \%$ by the OECD, a rate close to the current estimate by the Japanese government. Under the low-growth assumption of $1.7 \%$, which is more in line with estimates of potential growth, the necessary improvement in the primary budget surplus is $3.9 \%$ to $4.9 \%$ of GDP. See Chapter 3 of the 2008 OECD Economic Survey of Japan.

5. An increase of about one percentage point in the tax to GDP ratio could be associated with a direct reduction of about $0.3 \%$ in output per capita in the long run. If the investment effect is taken into account, the overall reduction would be about $0.6-0.7 \%$ (Bassanini and Scarpetta, 2001).

6. This is a about the same as during the period 2004-08, despite the acceleration in the potential rate of labour productivity growth in Japan from $2.0 \%$ to $2.2 \%$ in the $2009-2013$ period. However, the larger contribution from productivity is more than offset by the faster decline in the working-age population. 


\section{Box 2. Principles to guide tax reform}

In meeting the challenges for tax reform, Japan should seek the best possible balance between efficiency, equity and simplicity.

\section{Efficiency}

Raising taxes to resolve Japan's fiscal imbalance and to fund higher public spending required by population ageing will impose costs that will tend to slow economic growth. The deadweight costs (sometimes referred to as the excess burden) rise sharply as tax rates increase. ${ }^{1}$ Estimates of deadweight costs from taxes typically range from $10 \%$ to $100 \%$ (Diewert and Lawrence, 1994 and Leibfritz et al., 1997). Tax policies have a major impact on productivity and growth in both the short and long term as they affect all aspects of economic activity through their impact on incentives for savings, investment, employment and technological innovation. To limit distortions, the tax system should avoid introducing discrimination for, or against, any particular economic choices, except in certain cases, such as when there are clear externalities. In practice, this requires broadening tax bases, while minimising differences between tax rates. Understanding the magnitude and nature of the deadweight losses is important for assessing the true cost of increased government spending and for constructing an appropriate tax structure.

The impact of taxes on the behavior of economic agents and ultimately on economic growth varies between different types of taxes. Some taxes have a stronger effect on investment, while others influence incentives to accumulate human capital and accept employment. Other taxes affect technical progress through their impact on R\&D, foreign direct investment and entrepreneurship. Consequently, the structure of the tax system is an important factor determining growth.

There is substantial research indicating that, for a fixed amount of tax revenue, relying more on indirect taxes and less on direct taxes has a positive impact on GDP. According to research by the OECD, a stronger reliance on direct taxes, for a given overall tax burden, has a negative and statistically significant effect on GDP per capita (Bassanini and Scarpetta, 2001). The negative impact of direct taxes stems in part from the sensitivity of investment to corporate income taxes (Myles, 2007). In addition, personal income taxes impact employment as high tax wedges distort the labour market. ${ }^{2}$ According to one study, a 10 percentage-point reduction in the tax wedge on labour use (including income tax and social security contributions) is estimated to raise female employment and hours worked by $1 \frac{1}{2}$ and $31 / 2$ per cent, respectively (OECD, 2008). In contrast, a one percentage-point increase in the tax wedge on labour income would lower overall employment by $0.25 \%$ (Bassanini and Duval, 2006). While both personal and corporate income taxes are negative for growth, the impact of corporate income taxes is larger. The benefit of relying more on indirect rather than direct taxes and more on personal income rather than corporate income taxes is also supported by a study by Baylor (2004). It found that the welfare gain per $\$ 1$ of reduction in taxes was 40 cents for corporate taxes, 30 cents for personal income taxes and only 10 cents for consumption taxes.

\section{Equity}

Tax reform should also take into account equity considerations, even if this entails costs in terms of economic efficiency. Tax systems usually aim to achieve two forms of equity. Horizontal equity requires that taxpayers in equal situations should be taxed in an equal manner, suggesting that the tax on a given level of total income should be the same regardless of how that income is generated. Horizontal equity thus favours a comprehensive definition of income for tax purposes. Moreover, tax allowances and tax credits that are not directly linked to the generation of that income conflict with the objective of horizontal equity.

Vertical equity requires the "fair treatment" of individuals in different situations. It is a normative concept that depends on the definition of fair. One view of vertical equity is that taxpayers in better circumstances should bear a larger part of the tax burden as a proportion of their income, implying a more equal distribution of income after taxes than before. Achieving such an outcome requires progressive tax rates on income. Another definition of vertical equity favours proportional income tax (i.e. a flat tax rate). The approach to vertical equity depends on the extent to which countries want to diminish variations in income across the population.

\section{Simplicity}

The enforceability of tax rules and the cost arising from compliance are important considerations, and have implications for the efficiency of the tax system and public perceptions of its fairness. Tax systems are complicated by attempts to use them to redistribute income and to encourage certain behaviours. Complexity in the tax system also encourages tax planning, which imposes deadweight losses for an economy.

1. According to Creedy (2003), deadweight losses rise with the square of the tax rate.

2. The tax wedge measures the difference between total labour compensation paid by the employer and the net take-home pay of employees, as a per cent of total labour compensation. 


\section{Challenge 3: coping with widening income disparity}

10. Income inequality has been widening in Japan. Indeed, the Gini coefficient for disposable income rose by 13\% between 1985 and 2000, compared to an average increase of 7\% in the OECD area, according to cross-country comparisons by the OECD based on national data (Förster and Mira d'Ercole, 2005). ${ }^{7}$ While population ageing is boosting income disparity, as in most OECD countries, the key reason has been increasing income inequality among the working-age population in Japan, which is due in turn to two factors (2006 OECD Economic Survey of Japan and Tajika and Yashio, 2007). First, there has been a marked rise in inequality in market income, reflecting in part the increased proportion of low-paid nonregular workers. Second, the impact of the tax system on income redistribution has weakened as the personal income tax has become less progressive. The number of rates was reduced from 15 in 1986 to four in 1999, with a cut in the top rate from $70 \%$ to $37 \%$ (see Box 1).

11. Consequently, the reduction in the Gini coefficient due to the tax system declined from 2.2 percentage points in 1993 to between 1.3 and 1.4 points from 1999 to 2005 (Figure 5). The tax system now accounts for only about one-tenth of the difference between the Gini coefficients of market income and disposable income, while the social security system is playing a growing role in income redistribution as the population ages. However, this does little to reduce inequality among the working-age population, as only $11 \%$ of the working-age population received government benefits, about half of the OECD average of $20 \%$ (OECD, 2003). The combined impact of the tax and social security systems on income distribution for the working-age population is the lowest in the OECD area. ${ }^{8}$ Rising income inequality was accompanied by an increase in relative poverty, defined as a household income below $50 \%$ of the median, to $15 \%$ of the total population in 2000 , the fifth highest in the OECD.

Figure 5. The impact of taxes and the social security system on income distribution in Japan

Improvement in the Gini coefficient ${ }^{1}$

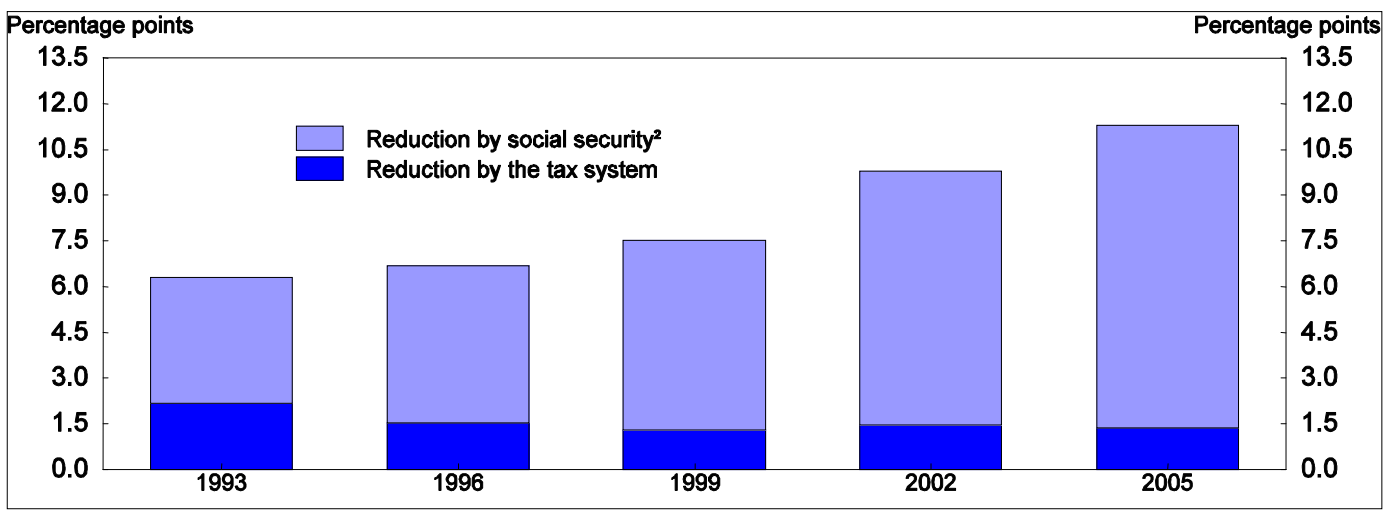

1. Based on equivalised household income. The Gini coefficient is multiplied by 100 .

2. Social security benefits in kind and social security payments minus social security contributions.

Source: Ministry of Health, Labour and Welfare (2005).

7. The Gini coefficient in 2005 was identical to that in 1999 according to calculations by the Japanese government.

8. According to an OECD calculation of Gini coefficients, the tax and social security system reduced the coefficient by 10 percentage points in Japan, the lowest of any OECD country (Förster and Mira d'Ercole, 2005). This corresponds with the calculation by the Ministry of Health, Labour and Welfare. 
12. Direct taxes on households fell from 8\% of GDP in 1990 to 5\% in 2005 (Figure 2). A salaried employee with a wife and two children earning the average salary of around 5 million yen $(\$ 46000)$ per year paid an average tax rate of $4.0 \%$ in 2007 compared to 7.8\% in 1986 (Ministry of Finance, 2007). For a salary of 30 million yen, the rate declined from $45 \%$ to $30.6 \%$ over that period. The relatively low effective income tax reflects generous allowances and deductions, notably for wage income. The wage deduction is 0.65 million yen on wages of up to 1.63 million yen and rises with income, though at a diminishing rate. ${ }^{1}$ There are a number of other exemptions and deductions, including those for spouses and dependent relatives, widows, the handicapped, working students, social insurance payments, premiums for life and casualty insurance, casualty losses and medical expenses, in addition to the basic exemption for all taxpayers. These deductions and exemptions add up to more than half of wage earnings.

\section{Challenge 4: improving the local tax system}

13. Providing greater autonomy to local governments would enhance their ability to innovate and respond to the preferences of local citizens. The "Trinity Reform" launched in FY 2002 transferred a substantial amount of tax resources from the central to local governments, while reforming earmarked grants and block transfers (Box 3). While the transfer of tax resources from the central government is a positive step in strengthening local government autonomy, there are a number of issues that should be addressed to improve the efficiency and equity of the local tax system. First, the gap between prefectures in per capita tax revenue is large, with the ratio between the richest and poorest remaining above three during the past 20 years (Figure 6). Second, a number of taxes at the local level duplicate and overlap with central government tax bases, thereby complicating the overall tax system. Third, although local governments have some discretionary powers to change tax rates, they have been used in a limited and often distorted way (2005 OECD Economic Survey of Japan). Fourth, a high reliance on corporate taxation at the local level leads to high volatility in local tax revenues, as profits tend to fluctuate much more than property values or consumption. The challenge is to create a simpler and more efficient local tax system that can provide sufficient resources and further increase local autonomy.

Figure 6. The gap in tax revenue across prefectures ${ }^{1}$

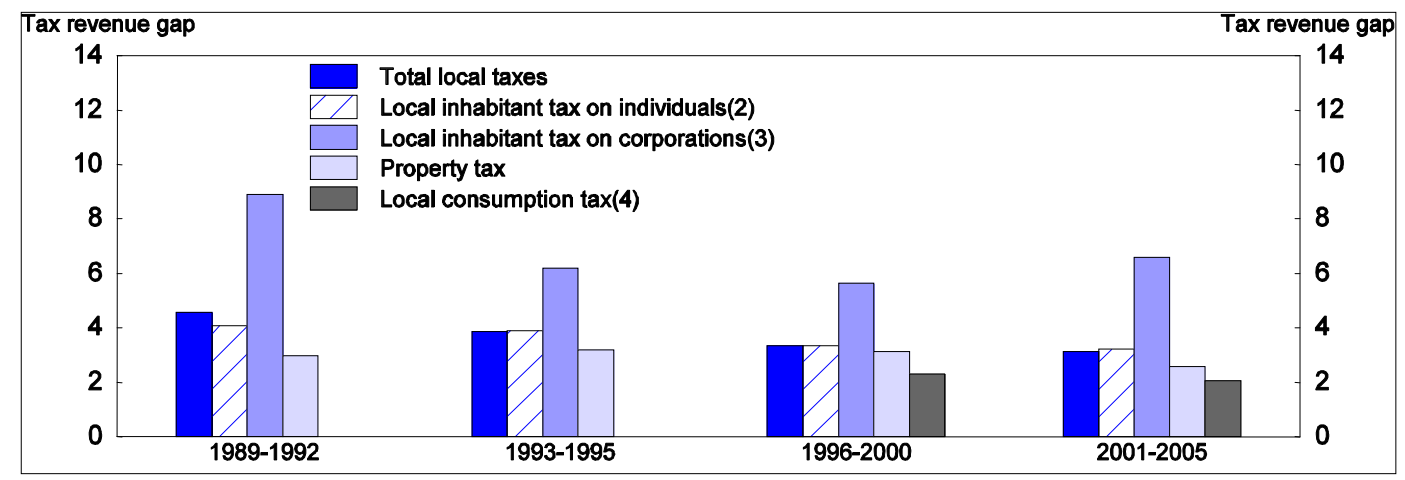

1. The ratio of the prefecture with the highest tax revenue per capita to the lowest. Population data are from the Basic Resident Register, as of 31 March each year.

2. Individual local inhabitant tax revenue is the sum of the individual prefectural inhabitant tax and individual municipal inhabitant tax.

3. Local corporation tax revenue is the sum of the prefectural corporate inhabitant tax, the municipal corporate inhabitant tax and the enterprise tax.

4. Local consumption tax revenue is after inter-prefectural adjustment. This tax was introduced in 1997.

Source: Ministry of Internal Affairs and Communications. 


\section{Analysis of the major taxes in Japan}

14. Meeting the complicated and inter-related challenges discussed in the previous section requires a comprehensive and prompt reform of the tax system. The limited progress in tax reform achieved since 1999 (Box 3) demonstrates the difficulty of implementing fundamental changes. However, further delaying reform would only impose higher costs on the economy in the years to come. At the same time, reform should be phased in so as to sustain growth.

\section{Box 3. Recent progress in tax reform in Japan: a follow-up of the 1999 Economic Survey of Japan}

The 1999 OECD Economic Survey of Japan pointed out a number of challenges in the tax system and called for a comprehensive reform. Despite some progress since then, many of the problems identified in 1999 remain unresolved, partly due to political obstacles and the complexity of the problems. In the meantime, the need for wideranging tax reform has become even more urgent with the further deterioration in the fiscal situation, accelerated population ageing and widening income inequality. The major recommendations in the 1999 Survey included:

i) Tax reform should cover a sufficiently broad range of measures (a "package approach") to make all groups contribute to the inevitable tax increases.

ii) Tax bases should be broadened substantially.

iii) Increasing the consumption tax rate gradually over a number of years should be one of the key financing mechanisms for the costs related to ageing.

iv) Taxation of pension savings should be stepped up in effective terms, at a minimum perhaps by reducing the indexation of retirement and annuity income allowances.

v) Social security contributions should be increased as projected in the draft 1999 pension reform.

vi) Corporate taxation is not in need of substantial reform but could be enhanced with a view to improving neutrality across financing and investment instruments.

vii) Tax administration should step up the efforts to control evasion - in particular among the self-employed.

viii) Local government taxes - in particular at the prefectural level - should be made less volatile and more equitable between firms that pay taxes and those that do not.

The most important step to boost tax revenue was the phasing out of the 1999 fixed-rate temporary tax cuts in the personal income and local inhabitant taxes in FY 2006-07. There have also been some measures to broaden the base of the personal income tax. Most importantly, the exemptions for spouses and elderly people were scaled back in 2004 and 2005, respectively. As for financial income taxation, a uniform tax rate of $20 \%$ was introduced in FY 2003 for interest, dividends from listed stocks and investment trusts and capital gains on listed stocks, while rates on dividends and capital gains on listed stocks are temporarily reduced to $10 \%$ as explained in Box 1 . As for the consumption tax, the base was broadened by reducing the threshold for exempting small retailers from 30 million yen in taxable sales per year to 10 million yen. In addition, the scope for using the "simplified tax scheme" to calculate the tax was reduced from 200 million yen to 50 million yen.

In contrast, the corporate tax base was narrowed by the introduction of R\&D and investment incentives in FY 2003 for three years, which resulted in an estimated 1.1 trillion yen $(0.2 \%$ of GDP) of foregone tax revenue per year. Although the temporary measures were largely terminated in FY 2006 as scheduled, the R\&D incentive for small and medium-sized enterprises (SMEs) was extended for another two years, while new measures, including a temporary tax incentive for acquiring information infrastructure, were introduced. Meanwhile, a part of the tax base for the local enterprise tax was changed in FY 2004 from profits to a "pro-forma" scheme that is based on capital and other value-added items such as wages. 
The "Trinity Reform" launched in FY 2002 reformed earmarked grants and block transfers and transferred around 3 trillion yen $(0.6 \%$ of GDP) of tax revenue from the central to local governments. This was accomplished by changing the tax rate schedule for the personal income tax to make it more progressive and replacing the three tax rates in the local inhabitant tax by a flat rate of $10 \%$ in 2007 (Table 1). Finally, the 2004 pension reform is boosting the pension contribution rate gradually each year from 13.6\% in FY 2004 to 18.3\% in FY 2017.

\section{The consumption tax}

15. Greater reliance on indirect taxes would help achieve the first two goals of restoring fiscal sustainability and supporting economic growth. The value-added tax rate in Japan is the lowest in the OECD area at 5\%, and is well below the EU average of $20 \%$ (Figure 7). As a result, indirect taxes on goods and services account for $19 \%$ of total tax revenue in Japan compared to an OECD average of 30\%. Substantial increases in revenue thus appear to be possible. Japan's consumption tax has a broad base, as reflected in its C-efficiency ratio, which was the sixth highest in the OECD area in 2003 (Panel B). The base of the consumption tax was further broadened in 2004, when preferential treatments for SMEs were scaled back (Box 3). Each 1 percentage-point hike in the tax rate would add about 2.5 trillion yen $(0.5 \%$ of GDP) of extra revenue. Raising the tax rate from $5 \%$ to $11 \%$, for example, would thus provide sufficient revenue to balance the primary budget on a general government basis (2008 OECD Economic Survey of Japan). While the revenue-raising capacity of the consumption tax, along with its other advantages noted below, make a hike in the consumption tax rate a key element of tax reform, it should not mask the necessity for base broadening of direct taxes, as well as for spending cuts.

16. Consumption taxes may have a negative impact on labour supply, as they reduce the return on labour by boosting the prices of goods and services. Nevertheless, a revenue-neutral move towards a consumption tax that raises the share of indirect taxes in total tax revenue would have a positive effect on growth, as noted in Box 2. In addition, it would increase consumption possibilities over the life cycle by lowering distortions on saving decisions. Indeed, the shift to a consumption tax makes taxation more neutral between present and future consumption, as income taxes are usually levied on a base that includes savings and income from savings. Another advantage is that indirect taxes are simple and relatively difficult to avoid or evade in Japan.

17. Regarding the third objective of improving income equality, a higher consumption tax rate would increase the effective taxation of the elderly, thereby contributing to a more equitable sharing of the tax burden across generations. However, the regressive nature of indirect taxes has negative implications for equity among the working-age population. Proposals to boost the consumption tax rate raise the issue of whether to introduce a multiple rate, an approach used in a number of countries, in order to limit its regressive impact by excluding food and other necessities. However, the tax rate in Japan is unlikely to approach the level in Europe, which goes as high as $25 \%$, weakening the argument for multiple rates. Moreover, such an approach should be avoided as it has several drawbacks. First, it would result in higher administrative costs and induce lobbying. Second, it would have to be compensated by a higher standard rate. Third, it would reduce the neutrality of the consumption tax, thus distorting consumption decisions and decreasing welfare. Fourth, it does little to reduce inequality, as high-income households that buy more goods in general tend to benefit most from lower rates on some items (OECD, 2006c). It is important to keep the simplicity of the current consumption tax while addressing income distribution objectives through better-targeted policy tools, such as an Earned Income Tax Credit (see below). 
Figure 7. Value-added taxes in OECD countries

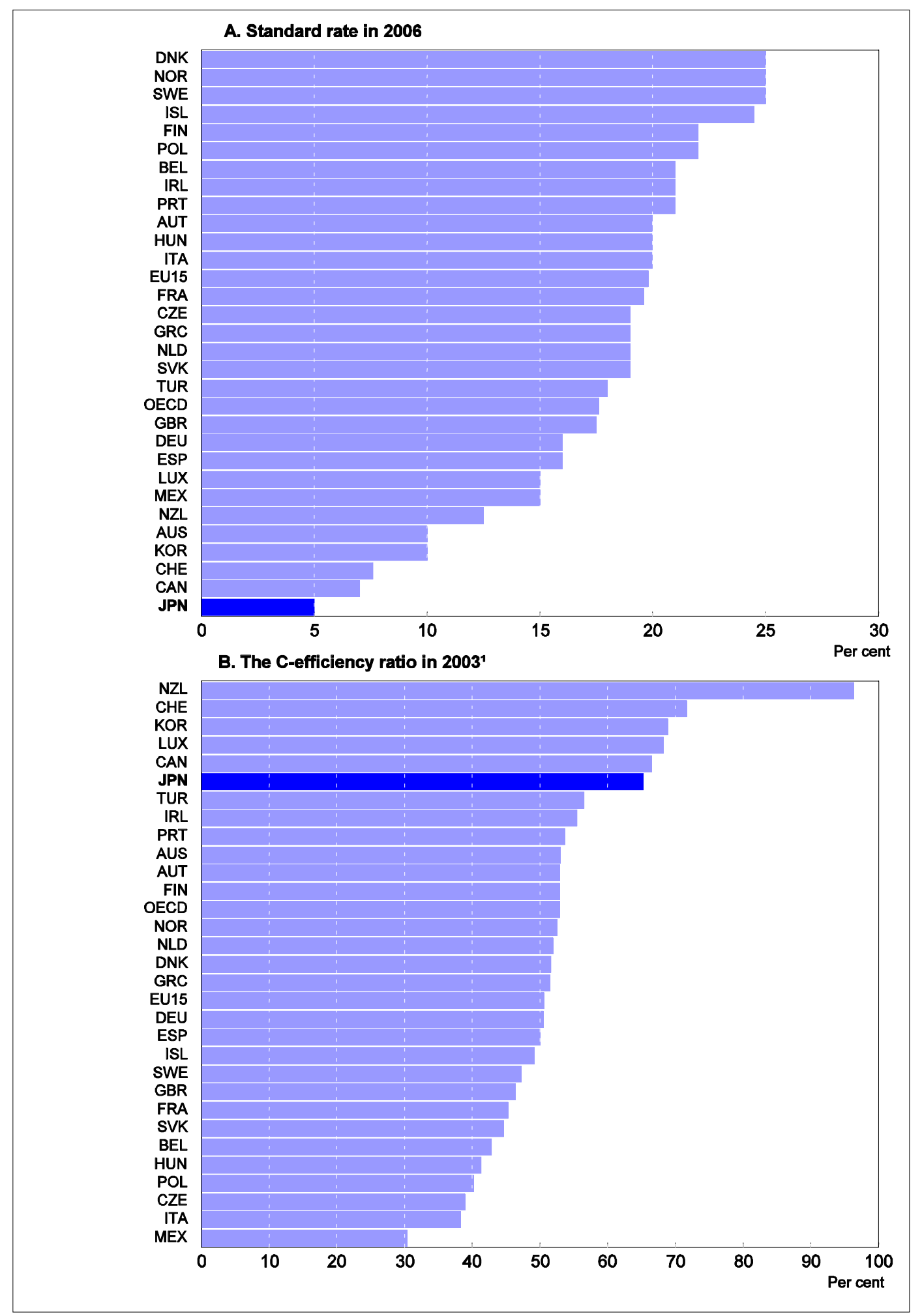

1. The C-efficiency measure is the ratio of value-added tax revenue to consumption spending divided by the standard tax rate. 2003 is the most recent year for which complete data are available.

Source: OECD (2006a), Consumption Tax Trends, OECD, Paris. 
18. A second issue is whether to earmark the tax revenue generated from raising the consumption tax rate. For example, it is often proposed that the additional revenue be earmarked for financing the scheduled hike in the government's subsidy rate for the basic pension from one-third to one-half in FY 2009 (a cost of $0.4 \%$ of GDP) and financing additional social spending (the government projects that social spending will rise by $0.9 \%$ of GDP by 2015). Earmarking the revenue for social security spending may make it politically easier to raise the consumption tax rate. ${ }^{9}$ However, earmarking is generally not an efficient way to manage public finances from a long-term perspective. First, it reduces the flexibility of policy makers to adjust spending programmes as needs change over time. Second, if revenues are more buoyant than the expenditure for which they are targeted, it is difficult to avoid extending the programme beyond its original objectives. Therefore, Japan should retain flexibility in allocating the additional revenues from tax reform.

19. As noted in Box 1, the local consumption tax rate $(1 \%)$ is set at a quarter of the national consumption tax (4\%). If the current scheme is maintained, an increase in the overall rate would thus boost the rate of the local consumption tax. In addition, $29.5 \%$ of national consumption tax revenue is currently transferred to local governments through the grant system. ${ }^{10}$ Increasing the role of the relatively stable consumption tax in local government revenue would reduce reliance on more volatile taxes, notably the local taxes on the corporate sector (see below).

\section{Corporate taxation}

\section{Raising more revenue}

20. The statutory corporate tax rate in Japan was the highest among OECD countries in 2006 (Figure 8). Moreover, the effective average tax rate of $32 \%$ and the effective marginal tax rate of $28 \%$ were well above the OECD averages of $24 \%$ and $20 \%$, respectively. Despite high statutory rates, corporate tax revenue, at an average of $3.6 \%$ of GDP during the first half of the 2000s, was close to the OECD average of 3.3\%, reflecting a number of tax expenditures in Japan and a high share of enterprises making losses and thus not paying tax. Broadening the tax base is therefore a priority. The number of tax expenditures fell from 80 in FY 2000 to 61 in FY 2007. However, their cost jumped from 5\% of total corporate tax revenue in FY 2002 to $18 \%$ in FY 2003 when temporary tax subsidies on R\&D and investment incentives were introduced (Figure 9). Although these measures were largely terminated as scheduled in FY 2006, the additional R\&D incentive for SMEs was extended for another two years, while new measures, including a temporary tax incentive for acquiring information infrastructure, were introduced (see the 2006 OECD Economic Survey of Japan).

21. The rate of tax subsidy for R\&D expenditures in Japan is relatively generous, ranking in the upper half of OECD countries (Figure 10). Some studies suggest that tax relief for R\&D can have a positive impact on R\&D spending. ${ }^{11}$ Such policies can be justified on the grounds that without it, investment in $R \& D$ would fall short of the socially optimal level due to spillover effects, with negative consequences for growth. However, some countries such as Finland and Sweden, which are generally seen as front-runners in innovation, do not provide any tax relief for R\&D. If Japan wants to have such tax incentives, it should ensure that the benefits of additional R\&D spending resulting from tax expenditures

9. The Basic Policy for Economic and Fiscal Management and Structural Reform in July 2006 stated: "To ensure a stable revenue source for social security benefits, the government will consider whether to clearly designate the consumption tax as a revenue source, taking into account the link between the benefit recipients and the revenue source" (see the 2006 OECD Economic Survey of Japan).

10. While the consumption tax is a convenient source of additional revenue for local governments, its impact on local autonomy would be limited as local governments cannot change the rate nor the base.

11. A permanent $10 \%$ increase in the tax subsidy for R\&D was estimated to raise the level of R\&D spending by over $8 \%$ (Jaumotte and Pain, 2005). 
outweigh the cost of those expenditures. If tax expenditures are in fact effective, it is questionable then why the additional special tax treatment is granted only to SMEs. With total tax expenditures amounting to $7 \%$ of corporate tax revenue - well above the average during the $1990 \mathrm{~s}$ - further efforts are needed to reduce the number and amount. Many of the tax expenditures were introduced several decades ago and have continued without any rigorous quantitative assessments of the cost and benefits. Broadening the tax base by reducing tax expenditures would make the system more efficient, thereby promoting growth.

Figure 8. Statutory corporate income tax rates

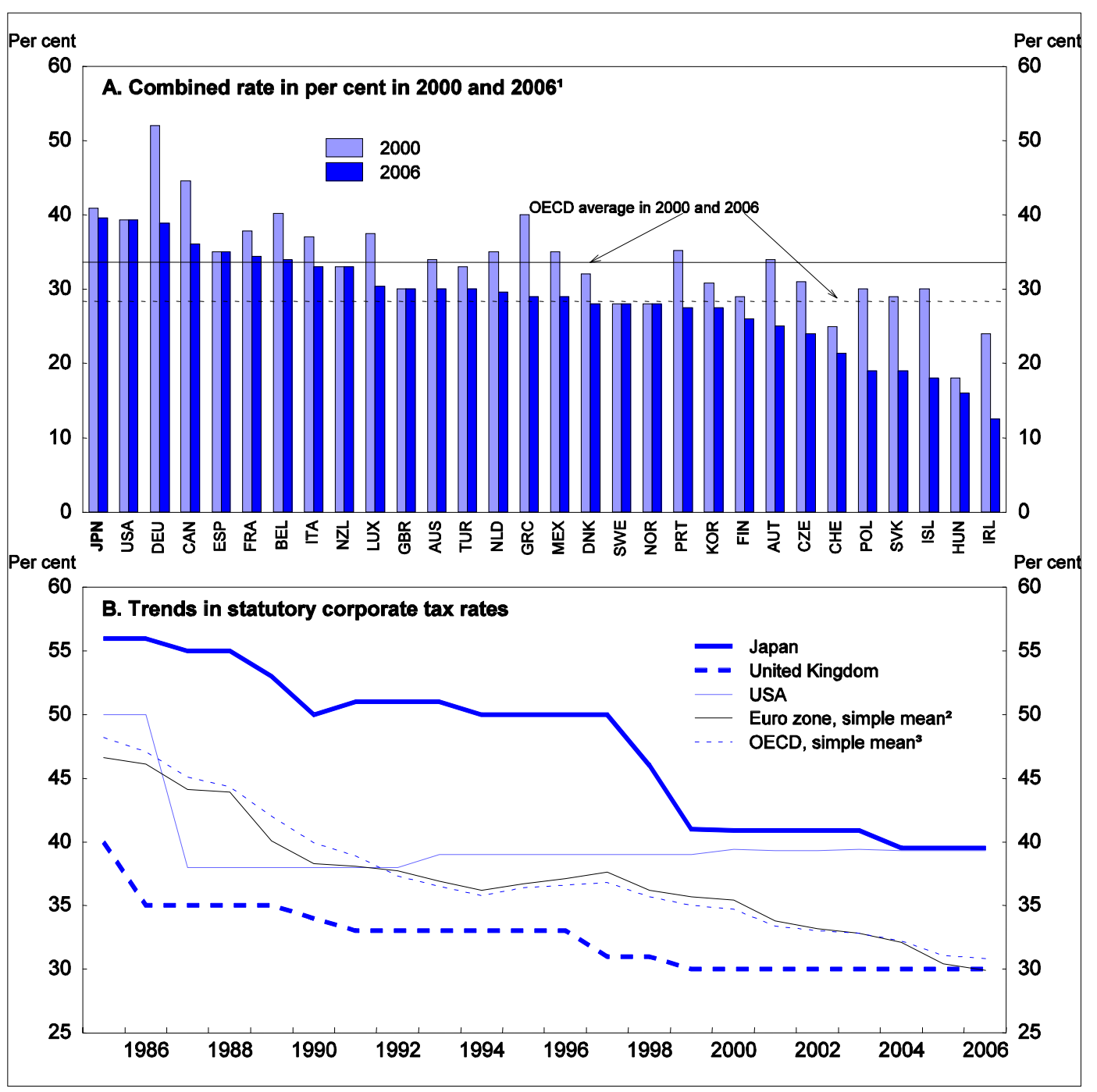

1. Basic combined central and sub-central (statutory) corporate income tax rate. Averages are un-weighted.

2. Excludes Luxembourg.

3. Includes 17 OECD countries.

Source: OECD (2007e), Tax Database, OECD, Paris (www.oecd.org/ctp/taxdatabase); European Commission (2006), Structures of the Taxation Systems in the European Union; and OECD (2007b). 
22. A large number of companies report losses according to the tax code and thus are not subject to corporate taxes (except for some local corporate taxes). The share rose to nearly $70 \%$ in 1999 before falling slightly in recent years (Figure 11). The proportion is higher for companies with capital of less than 100 million yen. The high corporate income tax rate gives family companies an incentive to use the generous deduction for employee expenses under the corporate tax code to shift profits to personal income, which is taxed at a lower rate for most taxpayers. However, this may discourage successful small companies from expanding, as that would presumably make it more difficult to shift profits into personal income. Even among large companies (more than 100 million yen of capital), the proportion not paying corporate tax has been close to half since the mid-1990s, reflecting issues related to the size of deductions, depreciation and the length of loss carryover. ${ }^{12}$ The introduction of pro-forma taxation in the local enterprise tax (see below) was intended in part to require companies reporting losses to pay taxes. However, taxation based on the size of the company has drawbacks. The government should instead aim at boosting the share of firms paying taxes by changing the tax code to reduce generous deductions and by introducing measures to improve compliance. At the same time, it is important to maintain loss carryover provisions, which help to encourage risk-taking.

Figure 9. Tax expenditures in the corporate tax system

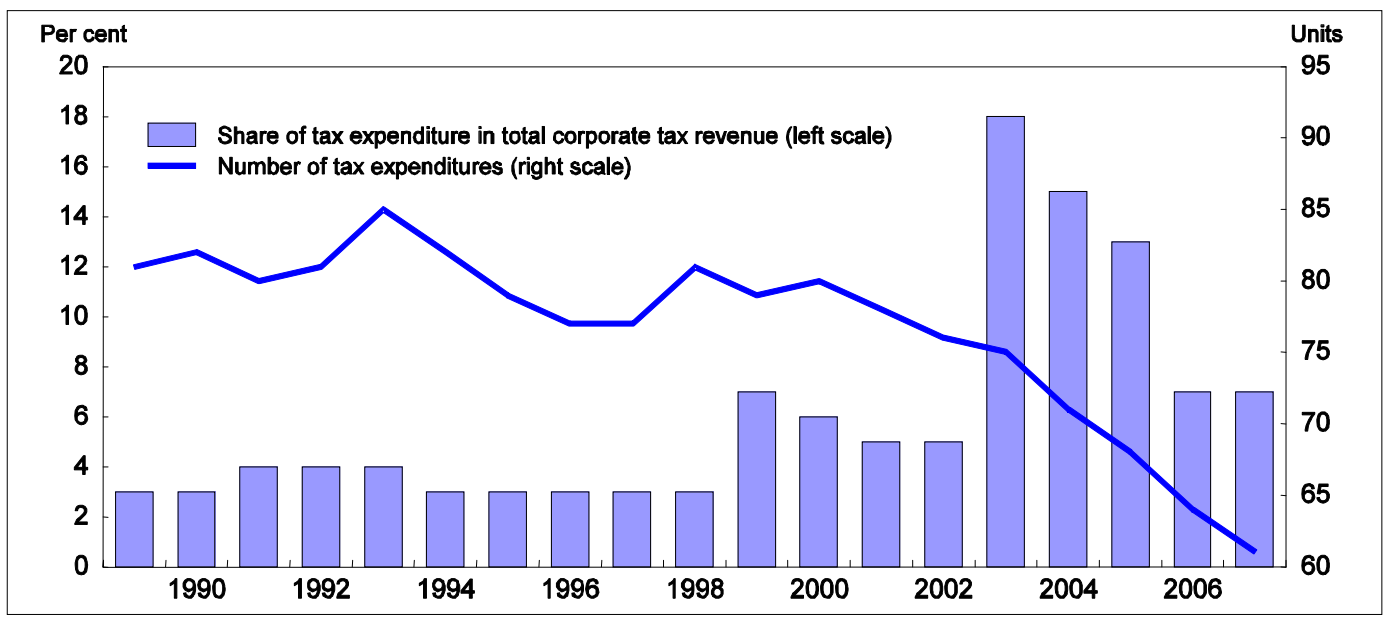

Source: Tax Commission and Ministry of Finance.

12. The aggregate operating revenues of loss-making corporations, at 474 trillion yen (95\% of GDP) in 2005, amounted to $33 \%$ of the aggregate operating revenues of all corporations (1 455 trillion yen, $290 \%$ of GDP). 
Figure 10. Tax treatment of R\&D in OECD countries

Rate of tax subsidy for one unit of R\&D in $2007^{1}$

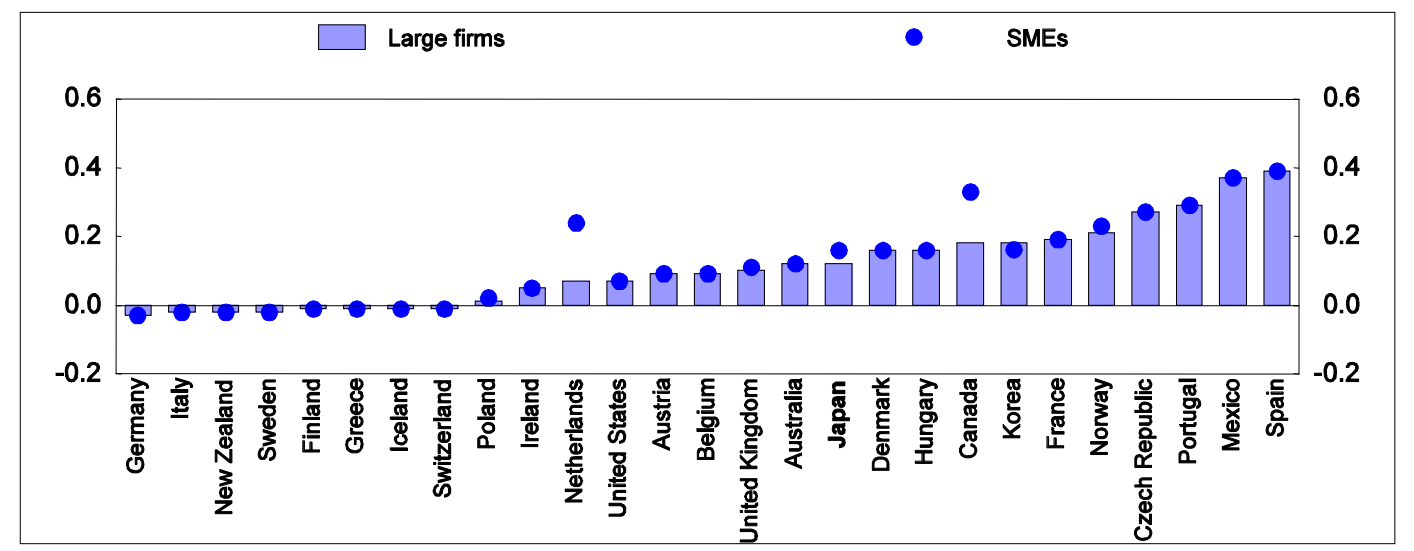

1. For example, the score of 0.12 for large firms in Japan means that 100 yen of R\&D spending resulted in 12 yen of tax relief for them.

Source: OECD (2007d), Science, Technology and Industry Scoreboard, OECD, Paris.

Figure 11. Proportion of firms making losses according to the national tax code

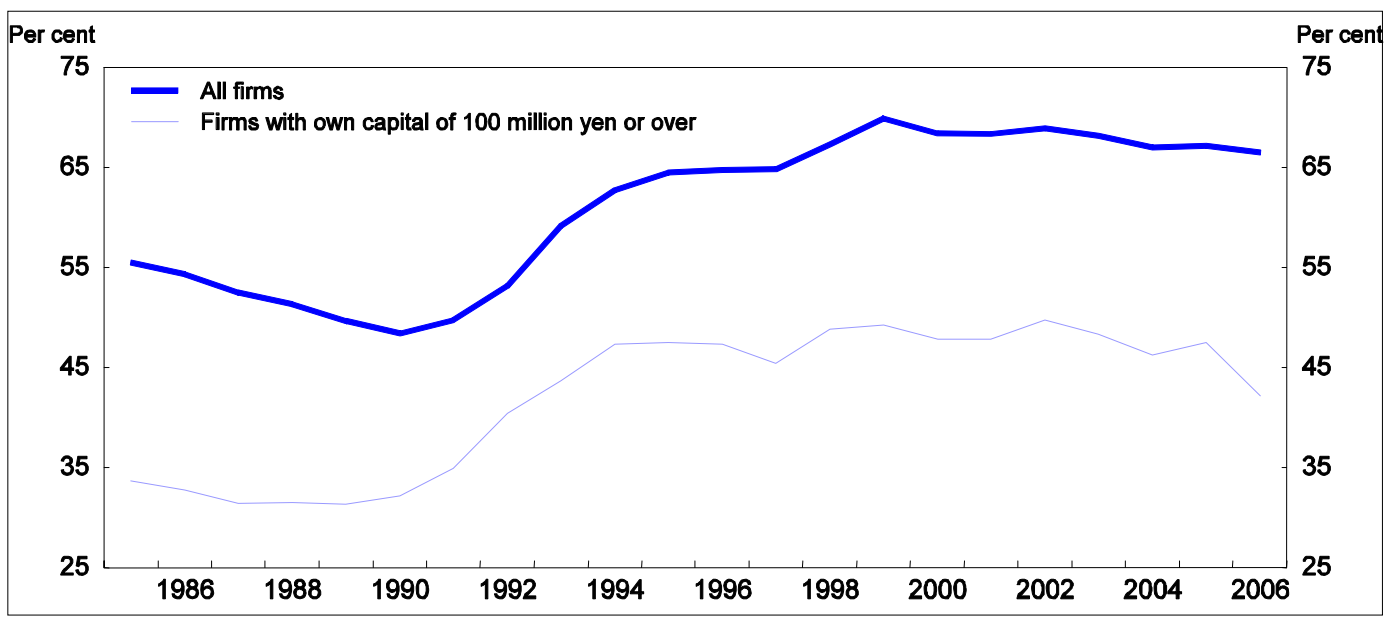

Source: National Tax Agency, Results of the Corporation Sample Survey.

Promoting economic growth

23. In addition to reducing tax expenditures, cutting corporate income tax rates would also promote the broadening of the tax base. The objective should be to shift the composition of direct taxes away from corporate income and towards personal income, which would also have a positive impact on growth, as noted in Box 2. This is based on evidence that a lower corporate tax rate leads to higher investment and 
faster economic growth. ${ }^{13}$ This has encouraged a downward trend in corporate income tax rates in the OECD area since the early 1980 s, reducing the average statutory rate from $48 \%$ to $31 \%$ in 2006 (Figure 8 , Panel B). Japan's rate has also fallen during the past few decades, notably in 1999, when the central government basic rate was lowered from $34.5 \%$ to $30 \%$. The worldwide fall in corporate tax rates has been motivated in part by the aim of attracting foreign direct investment (FDI) in a world of increasingly mobile global capital flows. There is evidence showing that differences in corporate tax rates affect international flows of capital and profits and the location decisions of firms. In addition, an OECD study (Hajkova et al., 2006) found that a one percentage-point increase in the effective corporate tax rate reduces the stock of FDI by between $1 \%$ and $2 \%$. Another study reported that a similar decline in the rate can raise the stock of FDI by about 3.3\% (de Mooij and Ederveen, 2003). Consequently, the ability to raise revenues through high tax rates on an internationally mobile tax base may be constrained in the context of an increasingly globalised economy and shifting attitudes toward tax compliance. However, economies with a large market potential, such as Japan, may be better able to sustain a higher tax rate than smaller countries.

24. International differences in corporate tax rates also create incentives for more aggressive use of transfer pricing by multinationals, which shift profits to subsidiaries in countries that have lower tax rates and costs to countries with higher tax rates, and this may be the case in Japan as well. Such transfers are facilitated by the increasing proportion of intangible assets, such as patents, in corporate assets. Indeed, intangible assets account for $75 \%$ of the total net assets of Fortune 500 companies, making it easier to relocate activities and tax bases around the world.

25. For Japan, the importance of additional government revenue should be balanced against the risk that high corporate tax rates will reduce economic activity and Japan's potential growth rate, in the context of growing international tax competition. Given the serious fiscal situation, the government has thus far resisted pressure from domestic business groups, such as Nippon Keidanren (2006), to reduce statutory corporate tax rates. However, the impact of lower tax rates on government revenues is likely to be limited by positive supply-side effects. Indeed, in some OECD countries, revenue was boosted by lower tax rates, thanks to higher profitability and the increased size of the corporate sector (2007 OECD Economic Survey of the United Kingdom). Indeed, the amount of taxable income in the corporate sector tends to be higher in countries with low corporate tax rates (Figure 12). Consequently, corporate income tax receipts show less variation across countries as the impact of higher tax rates is negated by the lower level of taxable income. As a result, there is almost no correlation between the statutory corporate tax rate and corporate tax receipts as a share of GDP (Panel B).

13. For instance, Uemura and Maekawa (2000) estimated that the cut in corporate tax and enterprise tax rates from $46.4 \%$ to $40.9 \%$ in 1999 resulted in an increase in business investment by $3 \%$. In addition, the high statutory tax rate makes the bias in favour of debt finance especially strong in Japan. 
Figure 12. International comparison of corporate taxes

Average 2000-05

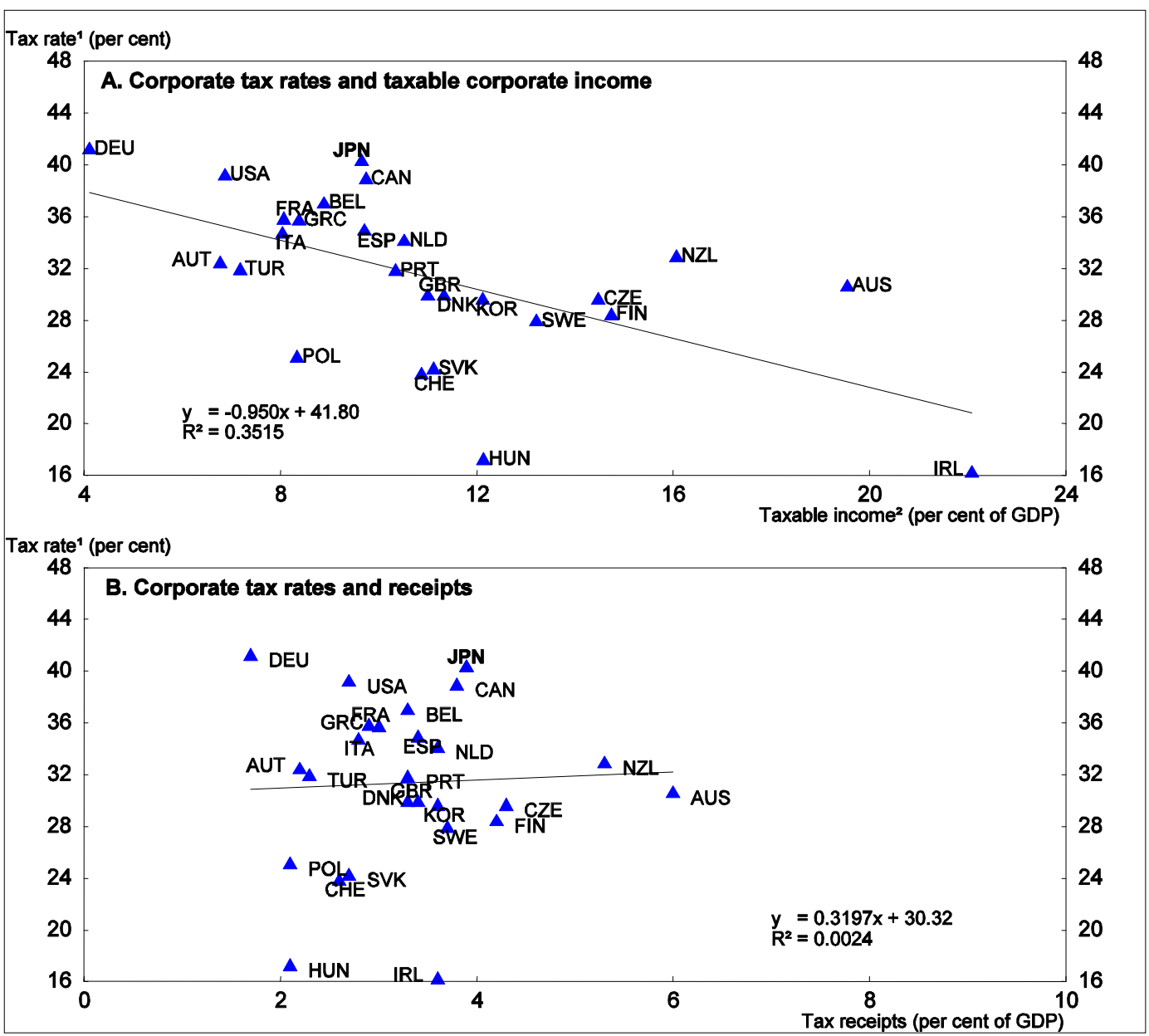

1. Combined central and sub-central statutory corporate income tax rate.

2. Calculated by grossing up corporate tax revenue and dividing by the tax rate.

Source: OECD (2007e), Tax Database, OECD, Paris (www.oecd.org/ctp/taxdatabase) and OECD (2007c), Revenue Statistics 1965-2006, OECD, Paris (http://dx.doi.org/10.1787/366725334503).

\section{Improving the local tax system}

26. One way to lower the corporate tax rate and improve the local tax system would be to phase out local taxes on enterprises, while increasing other local taxes, notably on personal income, property and consumption. A unique feature of Japan's corporate tax system is the significant amount that is imposed at the local level through the prefectural enterprise tax and the local inhabitant tax on corporations. Corporate taxation at the local level has various drawbacks such as the large revenue gap between jurisdictions - tax revenues per capita in Tokyo were nearly seven times higher than in the poorest prefecture between 2001 and 2005 (Figure 6) - and high volatility in revenue. These problems could be reduced by the pro-forma scheme introduced in 2004, which determines the enterprise tax on the basis of assets and value-added, as well as income. Such an approach can be justified by the benefit principle - even firms that are not profitable should pay for the services they receive. However, many OECD countries have phased out this type of taxation as it tends to discourage job creation and business investment. Moreover, it may exacerbate enterprise failures during economic downturns by transferring the cyclical risk from local 
governments to companies (2005 OECD Economic Survey of Japan). Given the numerous drawbacks, Japan should shift away from corporate taxation at the local level, which would reduce the overall corporate tax rate toward the OECD average.

\section{Personal income taxation}

\section{Raising more revenue}

27. As noted above, the fall in direct taxes on households since 1990 largely explains the downward trend in government revenue (Figure 2). The decline was caused by weak economic conditions that depressed personal income and changes in the tax system aimed at revitalising the weak economy. Some other OECD countries have also experienced a decline in personal income tax revenue during the past two decades as tax rates have been reduced. ${ }^{14}$ Nevertheless, the proportion of direct taxes in Japan remains well below the OECD average for several reasons. First, $60 \%$ of Japanese taxpayers are in the lowest tax bracket, with a $5 \%$ rate (15\% including the local inhabitant tax). Second, Japan allows a large number of exemptions and deductions. Despite the efforts to broaden the tax base in recent years, about a quarter of employees are exempted from the personal income tax. Moreover, less than $40 \%$ of wage income was subject to personal income tax in FY 2000 and FY 2005, according to the National Tax Agency (Figure 13). ${ }^{15}$ The Ministry of Finance's budget for FY 2007 assumed that the figure will rise to $45 \%{ }^{16}$ According to OECD statistics, the share of wage earnings subject to personal income tax (for a single person earning the average production worker's wage) averaged $82 \%$ in the OECD compared to less than $50 \%$ in Japan, the third lowest in the OECD (Panel B). The deductions from the personal income tax base reduced tax revenue by $5 \%$ of GDP in 2000 (Ishi, 2001).

28. Reducing deductions on wage income would substantially boost tax revenues. The largest income deduction, accounting for $28 \%$ of wage earnings, is for wage income itself (Figure 13). ${ }^{17}$ This deduction allows employees to exclude a certain proportion of their earnings based on their income level (see Box 1). The wage deduction was introduced to improve horizontal equity between wage earners and the selfemployed, whose income is difficult to fully capture. Indeed, a number of studies have shown significant differences in tax compliance between types of workers. According to a 2001 study, the proportion of income subject to tax (the "capture ratio") was $40 \%$ for farmers and $80 \%$ for other self-employed, compared to nearly $100 \%$ for salaried workers (METI, 2001). A more recent study concluded that the capture ratio of taxable income for the self-employed (excluding farmers) was $70 \%$ (Arai, 2007).

14. The share of personal income tax in total tax revenue in the OECD area fell slightly from an average of $27 \%$ in 1990 to $25 \%$ in 2005 , compared to a drop from $28 \%$ to $18 \%$ in Japan over the same period.

15. The tax base of salaried workers expanded slightly from 39.4\% in FY 2000 to $39.8 \%$ in FY 2005 as a result of the reduction of the special spouse deduction (2.0 percentage points), and the abolition of the deduction for the elderly ( 0.3 percentage points). However, this was offset by a negative 1.2 percentage-point contribution from the fall in the average salary and a negative 0.7 percentage-point contribution from higher social security premiums resulting from a hike in the contribution rate and population ageing.

16. However, it should be noted that the Ministry's estimate that $43.5 \%$ of wage income was taxed in FY 2002 was above the share of $40 \%$ calculated from National Tax Agency data.

17. Another major deduction is the category of "other deductions" (Figure 13), which includes ageing-related spending, such as pension contributions. With population ageing and hikes in the pension contribution rate, the amount of such deductions rose from $10 \%$ to $10.7 \%$ of total wage income between FY $2000-05$ and is likely to continue rising. In contrast, the deduction for dependents has fallen substantially following a drop in the number of children per household, while the reform in the special spouse deduction lowered the size of this deduction. 
Figure 13. Personal income tax

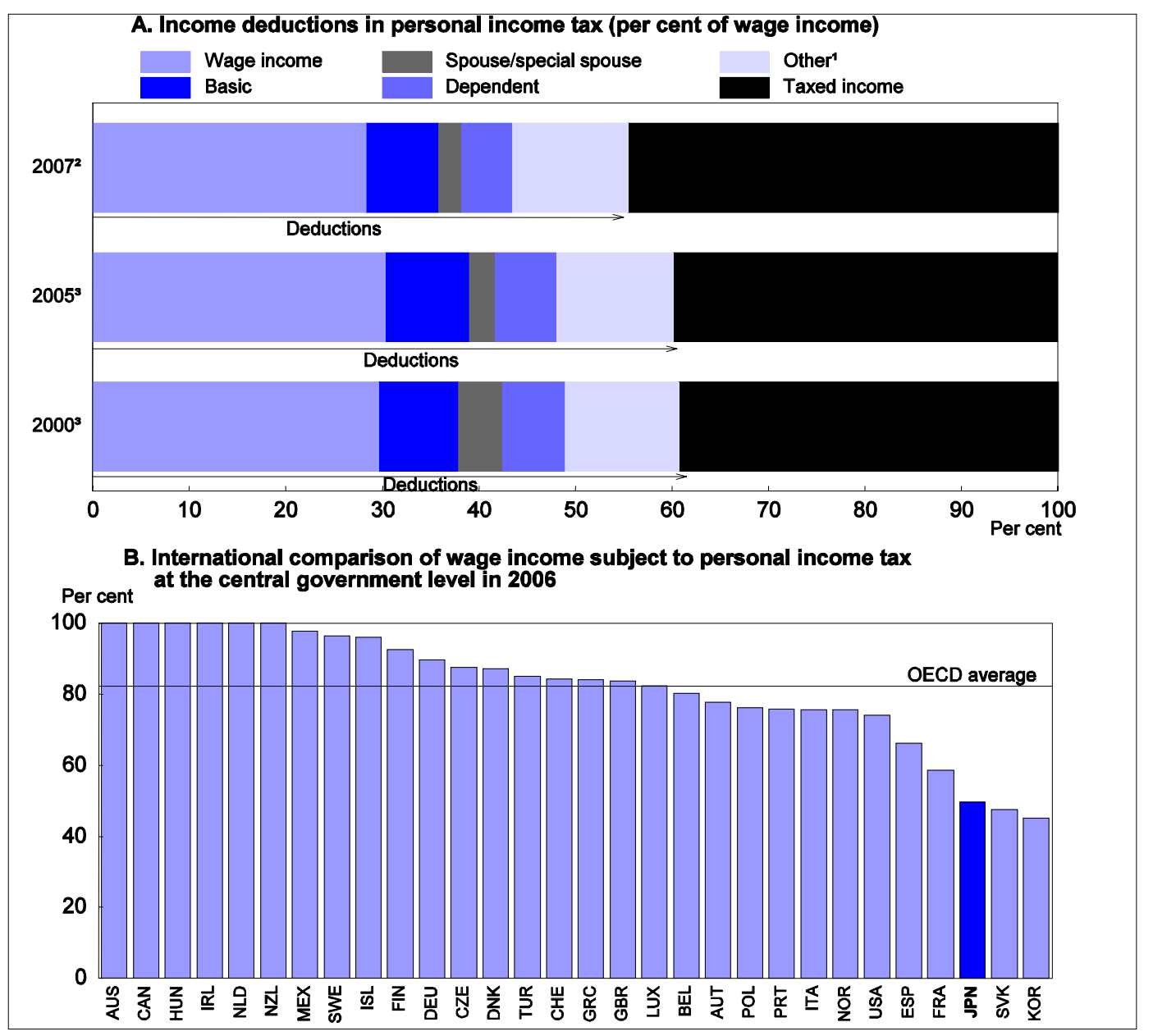

1. Primarily ageing-related deductions, such as pension contributions.

2. OECD calculations based on data from the Ministry of Finance, Explanation of Tax and Stamp Revenues in FY 2007.

3. OECD calculations based on data from the National Tax Agency, The Statistical Survey of Actual Status of Salaries in the Private Sector.

Source: Ministry of Finance, National Tax Agency and OECD (2006f), Taxing Wages 2005-2006, OECD, Paris.

29. The wage deduction for salaried workers helps to level the playing field by subjecting a similar proportion of income (around 45\%) to the personal income tax for both employees and the selfemployed. ${ }^{18}$ However, the wage deduction significantly narrows the tax base. Given that the amount of personal income tax receipts in Japan is low compared with other major economies, there is scope to reduce the wage income deduction, while improving the tax compliance of the self-employed to ensure equal treatment. Although there is no simple way to raise compliance, a package of measures may be effective. It should include the introduction of a taxpayer identification number and more intensive use of

18. Excluding the wage income deduction, the remaining deductions (basic, spouse, dependent and "other" shown in Figure 13) exempted $27 \%$ of wage income in 2007. For self-employed, those deductions excluded $35 \%$ of income. However, if only $70 \%$ of the income of the self-employed is captured by the tax system, then only $46 \%$ of their true income is subject to tax, well below the $73 \%$ for employees. The wage income deduction, which exempted an additional $28 \%$ of wage earnings in 2007 , brings the ratio down to $45 \%$, thus providing equal treatment of employees and the self-employed. 
information technology, thus freeing up resources of the tax authority to improve enforcement. In addition, stronger penalties for tax evasion are needed.

\section{Promoting economic growth}

i) Removing features of the tax code that distort the allocation of capital

30. Raising personal income tax revenue by lowering deductions, with offsetting declines in direct taxes on the corporate sector, would have a positive impact on growth (Box 2). Base broadening of direct taxes also accelerates growth by reducing distortions that result in a misallocation of resources. In addition to raising the share of wage income captured by the personal income tax, it is important, particularly in the context of population ageing and a declining saving rate, to remove features of the tax system that distort the allocation of capital. In principle, this requires eliminating non-neutrality in the tax system by integrating the taxation of all financial income at the same rate, while taxing it separately from other income. In addition, allowing loss carryover between various financial investments encourages risk-taking.

31. Under the FY 2003 reform, Japan has moved in this direction. The comprehensive income tax, in which financial income (interest, dividends and capital gains from financial assets) was taxed with other income, was replaced by a system in which most financial income is taxed separately at a uniform rate of $20 \% .{ }^{19}$ As noted in Box 1, the rate on dividend income and capital gains on listed securities has been temporarily reduced to $10 \%$ for five years in order to re-vitalise the stock market. This rate should be raised to the uniform 20\% in FY 2009 for dividend income and in CY 2009 for capital gains, as planned. In addition, the tax code allows capital losses on listed equities and trusts to offset capital gains on those assets, but not to offset interest and dividend income. In sum, it appears impractical and undesirable to return to comprehensive income taxation. Japan should instead maintain the separate taxation of financial income at a unified rate, an approach in line with international trends. Moreover, loss offset should be extended to all financial income, as recommended in the 2004 report of the Tax Commission.

\section{ii) Encouraging the supply of labour}

32. Cross-country research by the OECD suggests that taxes tend to reduce labour supply and demand, as well as saving and capital investment, thereby reducing the growth potential. The tax wedge on labour income in Japan was the seventh lowest in the OECD area in 2006 at 29\%, well below the OECD average of 38\%, thus encouraging employment and output growth (Figure 14). As noted in Box 2, an increase in the tax wedge on labour income reduces overall employment. On the other hand, a reduction in the tax wedge has the potential to significantly boost the labour supply of women. However, the decision on whether to cut personal income tax rates needs to take into account its impact on Japan's fiscal situation. While additional revenue should come primarily from a hike in the consumption tax rate, maintaining the amount of direct tax revenue should be an objective of tax reform. The scope for cutting personal income tax rates, while maintaining direct tax revenue, thus depends on the extent to which the broadening of the personal and corporate income tax bases generates additional revenue.

19. Under the Income Tax Law, taxable income is classified into the following ten categories and taxed on a comprehensive basis with some exemptions noted below: 1) interest; 2) dividends; 3) real estate; 4) business; 5) employment; 6) retirement; 7) timber; 8) capital gains; 9) occasional; and 10) miscellaneous. Retirement income and timber income are taxed separately from the other categories of income. Under the split-income model, interest, dividends and capital gains are also taxed separately. 
33. Even without rate cuts, it is important to address features of the personal income tax system that reduce growth. While the overall labour force participation rate in Japan is among the highest in the OECD area, reflecting a very high rate for men, the tax system appears to significantly discourage labour supply for certain groups, in particular second earners in households. For women in the prime age group of 25 to 54 years, the labour force participation rate is the sixth lowest in the OECD area (Figure 15). Moreover, $41 \%$ of female employees worked part-time in 2006, the third highest proportion in the OECD area and well above the average of $26 \%$ (Panel B). A number of features limit the female labour supply:

- Wages of a secondary earner up to a ceiling of 1.03 million yen per year (around a quarter of the average wage) are exempted from the personal income tax and the local inhabitant tax. ${ }^{20}$

- The main income earner in a household also qualifies for an income tax deduction of 380000 yen if the second earner makes less than 1.03 million yen per year. The special spouse deduction allows the main earner to take a portion of this deduction if the spouse earns between 1.03 and 1.41 million yen per year.

- The incentive to limit working hours is further reinforced by the fact that secondary earners with an annual income below 1.3 million yen are exempt from social insurance premiums for pensions, healthcare and long-term nursing care. ${ }^{21}$

- Many firms provide additional allowances to spouses earning less than a certain threshold, which is generally set at the same level as in the tax and social security systems.

Figure 14. International comparison of tax wedges

2006

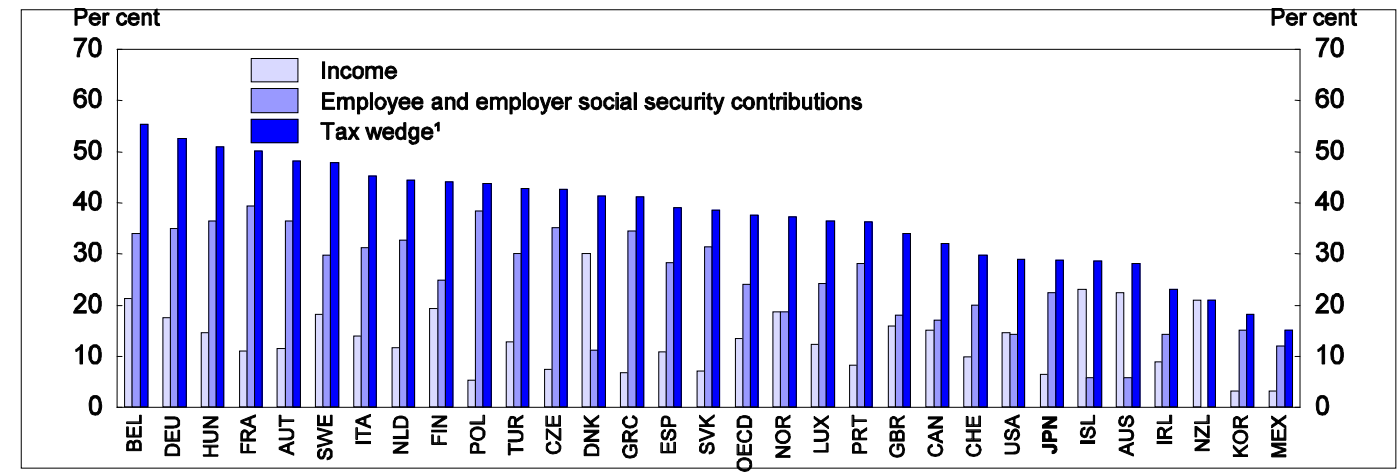

1. The tax wedge measures the difference between total labour compensation paid by the employer and the net take-home pay of employees as a ratio of total labour compensation. The international comparison of tax wedges is based on an individual with an income level of the average worker.

Source: OECD (2006f), Taxing Wages 2005-2006, OECD, Paris.

20. The local inhabitant tax consists of a per capita levy (kinto-wari) and an income-based levy (shotoku-wari). The exemptions apply to the latter. The per capita levy is a fixed amount imposed on those earning above a ceiling, which is around 0.98 million yen but varies between jurisdictions.

21. To qualify for the exemption, the second earner must work less than three-quarters of the working hours or days of regular workers and have a spouse that is covered by the insurance scheme. 
34. These features helped to ensure equal treatment of wage earners relative to the self-employed, who are able to shift a part of their income to family members and deduct it as a business expense. However, according to a government survey, these aspects of the tax system have a significant impact on female employees: i) $67 \%$ limit hours worked to avoid paying taxes imposed above the 1.03 million yen threshold; and ii) $46 \%$ limit hours worked so that their spouse can claim the income tax deductions for second earners. In addition, $27 \%$ limit hours worked in order to continue receiving company allowances for spouses (Ministry of Health, Labour and Welfare, 2007). Consequently, earnings of part-time female workers are concentrated near the threshold at which taxes are imposed (Figure 16). In 1994, when income up to 1 million yen was tax-exempt for secondary earners, $24 \%$ of female part-time workers earned between 0.9 and 1.0 million yen. In contrast, only $8 \%$ earned between 1.0 and 1.1 million yen in 1994, but the proportion jumped to $15 \%$ in 2000 , after the threshold for the tax exemption had been increased to 1.03 million yen. ${ }^{22}$ In 2005 , more than a quarter of female part-time workers earned between 0.9 and 1.1 million yen. The proportion would likely be substantially higher if the sample were limited to women who are secondary earners. As for male part-time workers, the share that earned between 0.9 and 1.1 million yen was $17 \%$. In addition to reducing labour inputs, the special treatment of second earners redistributes income from single workers and double-income couples to couples with a dependent spouse. Given the need to increase the labour supply, it is difficult to justify features of the tax system that encourage employees to limit their hours of work. Tax reform should therefore reduce the high marginal rates that discourage full-time work by second earners.

22. The threshold was increased in 1995. Presumably, a substantial proportion of those were in the 1.0 to 1.03 million yen range. 
Figure 15. International comparison of labour force participation rates and part-time employment

Per cent in 2006

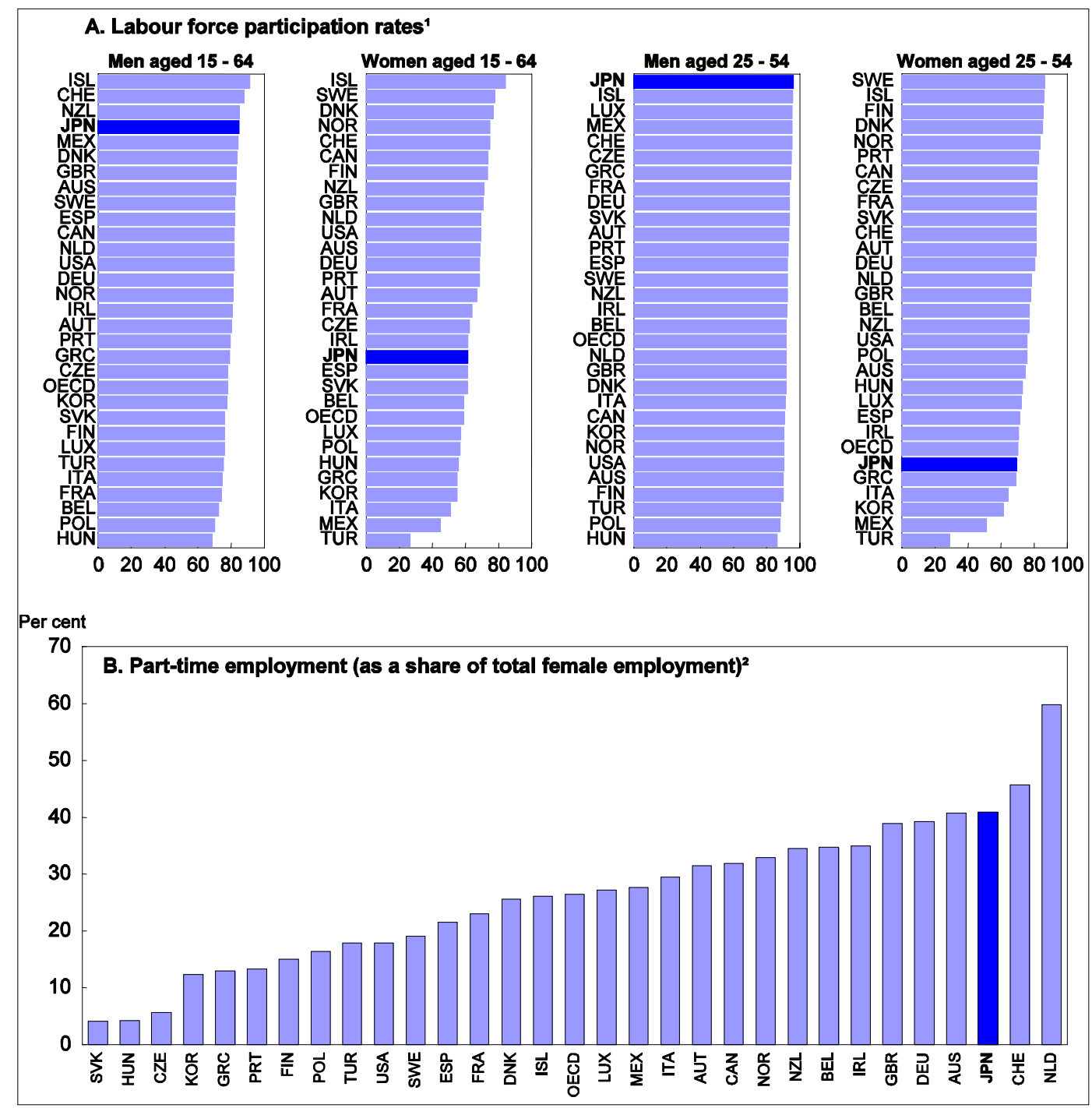

1. For Luxembourg, data is only available up to 2005

2. For Mexico, data is only available up to 2004.

Source: OECD (2007a), OECD Employment Outlook, OECD, Paris. 
Figure 16. Annual income of female part-time workers

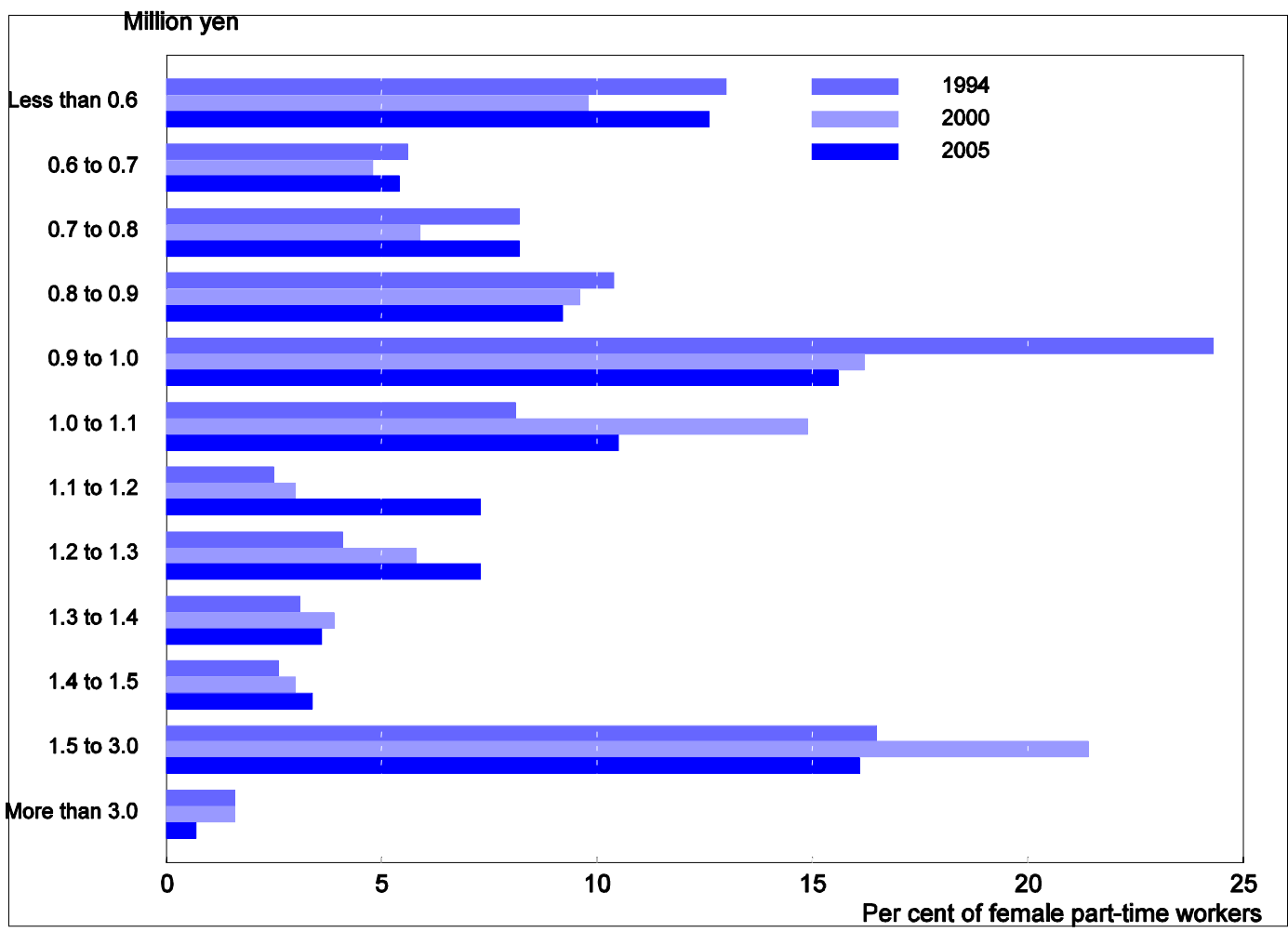

Source: Ministry of Health, Labour and Welfare (1996, 2002 and 2007).

\section{iii) Improving labour productivity}

35. The retirement allowance system, a lump-sum payment for departing employees that is voluntarily paid by most companies in Japan, is treated favourably by the tax system despite the fact that it discourages labour mobility. ${ }^{23}$ Moreover, the amount of the allowance subject to tax is reduced as the length of service increases. ${ }^{24}$ For example, the tax base of a worker who receives a lump-sum retirement allowance of 20 million yen for 30 years of service is 2.5 million yen, resulting in an income tax payment of only 153 thousand yen (an effective rate of $0.8 \%$ ). For a worker with 15 years of service, the effective tax rate would be almost $5 \%$. The favourable tax treatment of a system that discriminates against workers who change jobs and the fact that the extent of the favourable tax treatment increases with job tenure combine to discourage labour mobility. The tax treatment should be reformed to encourage labour mobility, which needs to be enhanced in Japan to promote innovation and productivity (2006 OECD Economic Survey of Japan). Given that the retirement allowance is considered to be part of pension income, its taxation should be harmonised with that on benefits from the pension system.

23. More than $95 \%$ of companies with over 100 employees pay a lump-sum retirement allowance, and $63 \%$ of them use a system in which the allowance rises more than proportionally with tenure (Ministry of Internal Affairs and Communications, 2001). Such an approach tends to discourage labour mobility.

24. The number of years multiplied by 0.4 million yen is deducted for a length of service of up to 20 years, and the number of years times 0.7 million yen is deducted for service beyond 20 years. 
36. Average and marginal tax rates on different types of income can affect the internal rate of return to education and thereby the level of human capital and labour productivity. Tax policies can thus be important drivers of investment in education through their effects on opportunity costs (i.e. foregone earnings), net wages and unemployment and pension benefits. A recent OECD study shows that a one percentage-point increase in the marginal tax rate reduces the internal rate of return to tertiary education by about 0.1 percentage point (Oliveira Martins et. al, 2007). The net effect of raising personal income tax rates to increase progressivity would be to reduce the education premium and thereby discourage human capital formation. In Japan, the degree of progressivity in the tax system is relatively low, suggesting that the negative effect on human capital is limited. Indeed, the ratio of income tax and employee contributions paid by a single person earning two-thirds of the average wage of a production worker was almost $80 \%$ of that paid by someone earning two-thirds more than the average, a high ratio compared to other OECD countries (Figure 17). The weak degree of progressivity in the personal income tax system thus has a positive impact on both labour inputs and on human capital and labour productivity. Maintaining the relatively low degree of progressivity, or even reducing it further subject to the fiscal constraints, would be beneficial for Japan's growth potential.

Figure 17. Indicators of progressivity in OECD countries

Ratio of the tax burden for a low-income person relative to a high-income person ${ }^{1}$

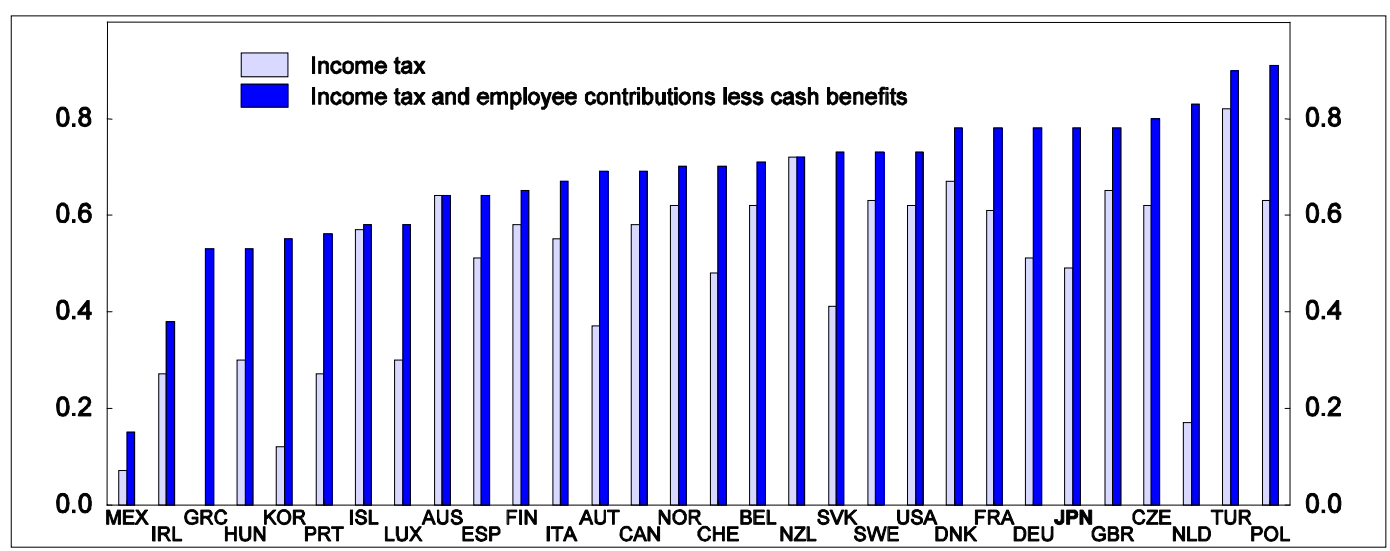

1. Progressivity is assessed by comparing the tax burden of a single worker (without children) earning $67 \%$ of the average production worker to one earning $167 \%$ in 2005.

Source: OECD (2006f), Taxing Wages 2005/2006, OECD, Paris.

\section{Coping with widening income distribution}

37. However, the weak progressivity of tax rates, combined with the narrow tax base, limit the redistributive impact of the personal income tax system. While the top rate is $40 \%$, some $60 \%$ of taxpayers are in the lowest (5\%) tax bracket (15\% including the local inhabitant tax. In addition, the progressivity of the tax system is partially offset by the regressivity of social security contributions (Figure 18). Currently, the most important tool for income redistribution is the inter-generational transfers that take place through the pension system.

38. Tax allowances tend to benefit higher-income groups since low-income people are already exempted from income tax. The abolition of the basic allowance, as well as the allowances for dependents, spouses and social security payments, would substantially increase the tax burden of persons with incomes of 5 million yen (the average wage) or more (Figure 19). For example, the proportion of taxpayers receiving the spouse deduction was more than $70 \%$ for those with an income above 10 million yen, compared to only $20 \%$ for those with an income between 2 and 3 million yen (Cabinet Office, 2002b). 
Consequently, abolishing or reducing allowances and deductions would reduce differences in disposable income and could be used to finance targeted (means-tested) transfers or tax credits to low-income groups. It should be noted that broadening the tax base would raise effective marginal rates on labour, thus tending to weaken work incentives. If the base broadening generated sufficient revenue, Japan should thus consider reducing personal income tax rates to offset the impact of base broadening. Another important option to strengthen income redistribution through the tax system is the introduction of an Earned Income Tax Credit (EITC) system (Box 4).

Figure 18. Tax and social security payments by income decile

Per cent of income ${ }^{1}$

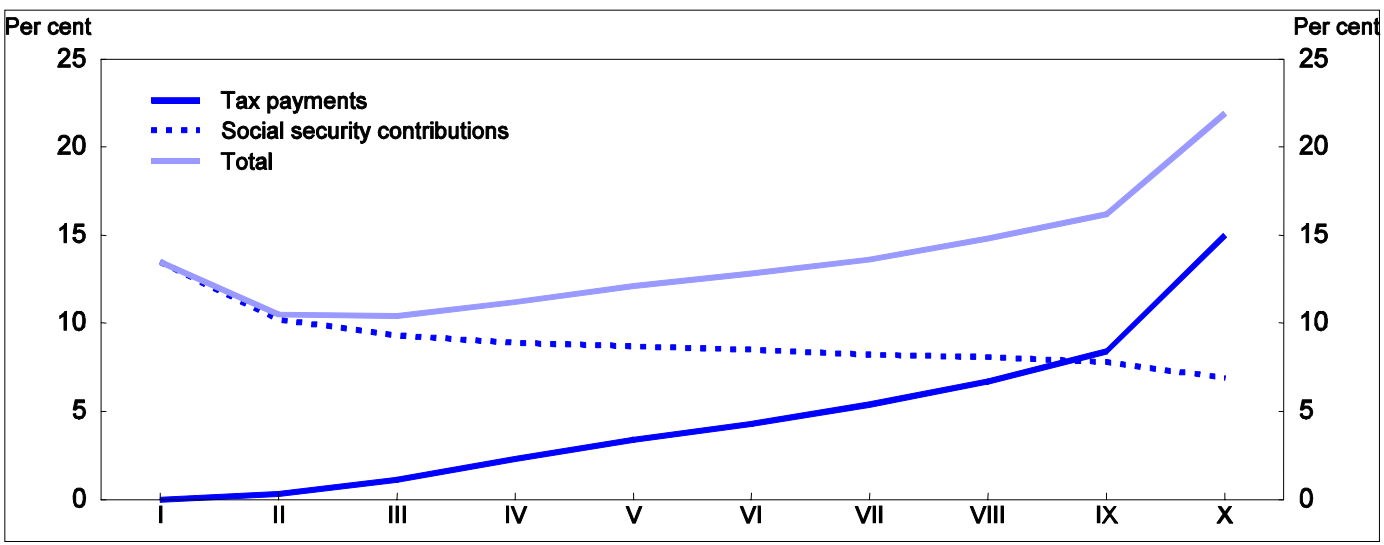

1. For households receiving salaries. I represents the lowest-income decile.

Source: Tajika and Yashio (2007).

Figure 19. Impact of abolishing personal income tax deductions

By income category of taxpayer ${ }^{1}$

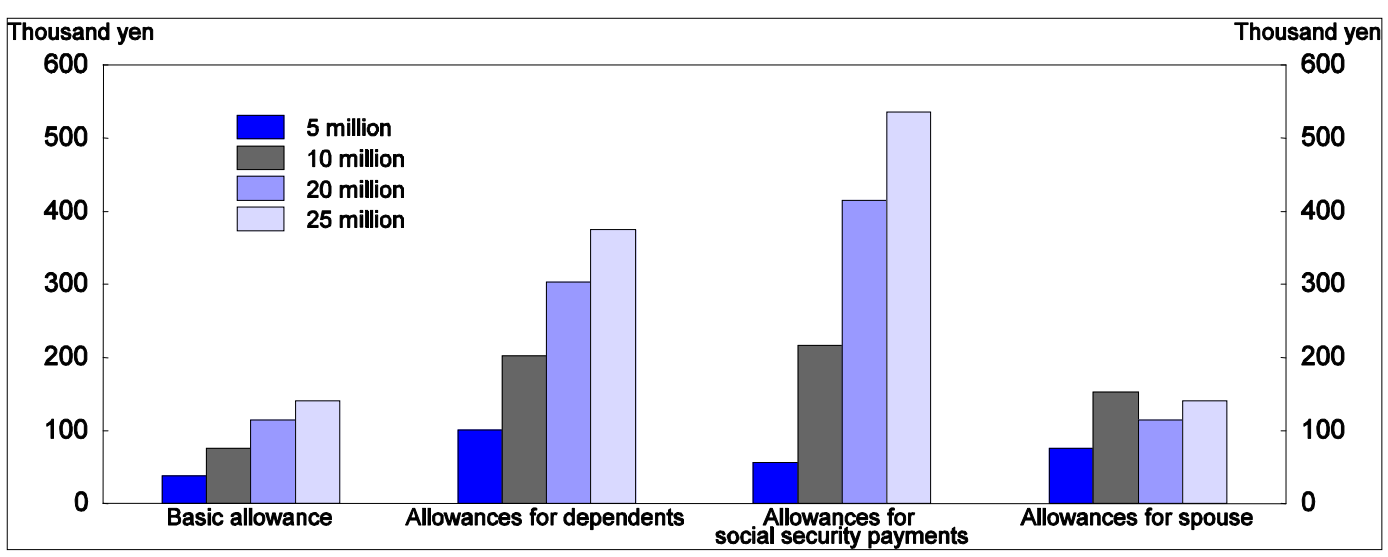

1. Per person in each annual income group. Wage earner with a spouse without a job and two children (the employed parent is eligible for the special dependent allowance).

Source: Cabinet Office (2002b). 


\section{Box 4. Earned Income Tax Credit systems in OECD countries}

In-work tax credits can help "make work pay" for the low-skilled, thus encouraging them to enter the labour market and to increase their work efforts. In addition, an Earned Income Tax Credit (EITC) can allow more targeted policies, such as supporting households with children. A number of OECD countries have introduced EITCs:

- The EITC introduced in the United States in 1975 has been especially successful at encouraging the employment of single parents, particularly mothers (2007 OECD Economic Survey of the United States).

- In the Netherlands, an EITC was introduced in 2001 by eliminating existing income deductions. The collection of income tax and social security contributions by the same agency makes it possible to give income tax credits through reductions in social security contributions (Tajika and Yashio, 2007).

- Denmark introduced an EITC in 2004 that does not gradually phase out as incomes rise, making the system expensive and increasing the deadweight losses. However, phasing out the EITC as incomes rise, a typical feature of schemes in other countries, would be problematic in Denmark as it would imply a significant rise in the effective marginal tax rates for a large number of workers, given the relatively compressed wage distribution. The EITC will be expanded in 2008 (2008 OECD Economic Survey of Denmark).

- In 2007, Sweden introduced an in-work tax credit, which will cost over $1 \frac{1}{4}$ per cent of GDP, partially offset by a reduction in unemployment benefits. The tax credit effectively reduces the marginal effective tax rate by 4 percentage points for those with incomes between $40 \%$ and $95 \%$ of the average full-time earnings. By increasing the attractiveness of work relative to unemployment, this reform is likely to improve employment rates and lower structural unemployment (2007 OECD Economic Survey of Sweden).

- In the United Kingdom, the Working Families Tax Credit for low-income families and single-parent households has been successful in raising the disposable income of the poorest workers relative to the median since 1999. This in-work, means-tested benefit has now been replaced by the Working Tax Credit, which tops up the earnings of low-income persons working more than 16 hours per week who are responsible for children and more than 30 hours for those without children. In addition, the disabled and persons over age 50 who are returning to work after a period of receiving unemployment benefits are also eligible. In 2006, almost 2 million households received the Working Tax Credit (2007 OECD Economic Survey of the United Kingdom).

Japan is discussing the costs and benefits of introducing an EITC. ${ }^{1}$ The employment effects of such a system depend on the potentially offsetting income and substitution effects and the increase in marginal tax rates as the subsidy fades out. The effectiveness of an employment-conditional tax credit, in terms of increasing total labour supply and decreasing unemployment, depends on the ex ante distribution of market earnings, the tax system and the level of benefits for non-employed persons (Bassanini, Rasmussen and Scarpetta, 1999). Not surprisingly, an EITC has better results in countries with a wide earnings distribution, low tax rates on labour and low benefits for the non-employed, such as the United States and the United Kingdom. In contrast, an EITC is costly in countries, such as Denmark and Sweden, with a compressed earnings distribution and high taxes on labour. The criteria noted above suggest that an EITC would be an effective approach in Japan, as it has a relatively unequal income distribution (see above) and low taxes on labour income (Figure 14). Moreover, strict eligibility conditions and the short duration of unemployment benefits in Japan reduce the proportion of unemployed receiving benefits to $34 \%$ compared to an OECD average of $92 \%$, while the generosity of benefits, with an average replacement rate of $67 \%$, is in line with the OECD average of $62 \%$. Other government transfers are quite limited in Japan. The proportion of the population receiving government benefits is small, as noted above, and benefits to the lowest income decile amounted to only $2.7 \%$ of household disposable income in Japan compared to an OECD average of 4.6\% (2006 OECD Economic Survey of Japan).

In sum, an EITC is likely to have a positive effect on aggregate employment and income distribution in Japan. ${ }^{2}$ However, there is a high possibility of fraud, given the difficulties noted above related to the taxation of the selfemployed. The introduction of a tax identification number system, proposed above to improve the tax enforcement of the self-employed, would also help to minimise such a risk. In addition, it is important that the EITC be based on individual income, rather than household income, to avoid weakening work incentives of spouses. ${ }^{3}$ In any case, the improvement in income distribution and employment through the introduction of an EITC will need to be weighed against the amount of fiscal resources needed to finance such a system.

1. This was part of the work of the Tax Commission in 2007.

2. There is a growing body of evidence suggesting that an EITC has a positive effect on aggregate employment (OECD, 2004).

3. The EITC in Belgium is moving from a household to individual income base for this reason (2007 OECD Economic Survey of Belgium). 
39. One of the most important allowances in the personal income tax system in Japan is for social security payments. In theory, taxation of pensions can take place at three stages: when contributions are made to the pension scheme, on the earnings from the investment in the scheme and on the benefits that are paid out. In most OECD countries, the first two stages - contributions and interest - are largely tax exempt. When the first two stages are tax exempt, there is a strong case for taxing benefits. The Japanese tax system is generous in its treatment of the public pension system, as contributions and accrued interest are completely exempted and the tax on benefits is only partial, due to the allowances granted to persons over the age of $65 .{ }^{25}$ Such allowances were scaled down by the abolition of some special treatments for elderly people as part of the FY 2004 tax reform (see Box 3). Nevertheless, the personal income tax threshold for households receiving pension benefits is $30 \%$ higher than for wage earners, making benefits from both tiers of the public pension system - a basic pension provided to all insured persons and a second tier linked to individual income - largely exempt from taxes. ${ }^{26}$ Given that one-third of the basic pension is financed by the current budget, this implies a significant income transfer from working-age persons to those who are retired. Moreover, the proportion financed by the budget is to be raised to one-half beginning in FY 2009.

40. Private pension plans also receive favourable tax treatment in many countries, reflecting concern that workers tend to consume too much during their working lives and free ride on the social safety net once they are retired. ${ }^{27}$ In Japan, the so-called "third tier" of corporate pension plans includes a number of schemes that receive preferential tax treatment. Depending on the decision of management and the labour union, employees can join the Employees' Pension Fund (EPF, created in 1966), the Tax-Qualified Pension Plan (TQPP, created in 1962 and scheduled to be abolished by the end of FY 2011), Small Enterprise Retirement Allowance Mutual Aid (created in 1959), the defined benefit corporate pension (DB, created in 2002) and/or the defined contribution pension (DC, created in 2001). For the self-employed, the government established the National Pension Fund (NPF) in 1991 to provide fair treatment relative to employees. Self-employed persons are also eligible to join the DC scheme. Contributions to third-tier pensions are usually tax deductible. ${ }^{28}$ At the asset management stage, the special corporate tax is supposed to be levied on the assets, although this has been postponed. ${ }^{29}$ At the withdrawal stage, the pension deduction is applied to benefits and the deduction for retirement income is applied for lump-sum payments, resulting in weak taxation of benefits.

25. Japan is among the 12 OECD member countries where pensions are partially taxed at the withdrawal stage but exempt at the contribution and accrual stages - a so-called EEpT regime (Yoo and de Serres, 2004).

26. The personal income tax threshold for a couple receiving a pension is 2.05 million yen, $30 \%$ higher than the 1.57 million yen threshold for a working couple without children (Miyauchi, 2006).

27. The Workers' Property Accumulation System is another tax preferred savings scheme for three types of savings; general, pension and housing savings. Interest is tax-deductible up to a certain combined amount for the three types of savings. Despite the favourable tax treatment, both the number of contracts and amounts have been falling. The number of contracts fell from 14.2 million in 2001 to 10.8 million in 2007 while the amount declined from 19 trillion yen (3.8\% of GDP) to 17.5 trillion yen over the same period.

28. In the EPF, the contribution of the employer is deductible as an expense and that of the employees is deductible as a social insurance premium. In the TQPP and DB, employer contributions are deductable as an expense, while employee contributions are deductible by the same amount as the deduction for private life insurance premiums. In the DC scheme, employer and employee contributions are deductible, although there are deduction limits. Similarly, contributions to the NPF are deductible up to a certain level.

29. Private investors argue that the treatment of interest on third-tier schemes should match the tax exempt status applied to the public pension system. One concern is that the tax rate $-1 \%$ of outstanding assets - is inappropriate in the current low interest rate environment. 
41. The benefits from exempting pension plans from taxes should be carefully weighed against the costs, particularly in the context of rapid ageing. There is no solid evidence that preferential tax treatment of savings leads to a higher aggregate level of national savings (Yoo and de Serres, 2004). Such policies to promote pension saving may thus have high deadweight costs while benefiting high-income groups that will earn pension income that is well above the social safety net. While not increasing the total amount of savings, favourable tax treatment of pension plans tends to distort the composition of household savings and reduce government tax revenue. In the case of Japan, tax incentives bias savings toward pension plans and against individual investments, including purchases of equities. To restore neutrality between financial products and promote equity investment, tax subsidies to public and private pension plans should be scaled down.

42. Another area favoured by the tax system in many countries is home ownership. The favourable treatment of home ownership compared to other types of personal savings is motivated by social policy objectives, such as helping middle-income groups to acquire housing. In Japan, the 2004 mortgage tax credit, which was available to those earning less than 30 million yen (five times the average wage), accounts for the largest amount of foregone tax revenue among all tax subsidies. However, it risks favouring higher-income groups, who face a comparatively high marginal income tax rate and can afford the investment necessary to qualify for the tax subsidy. It also significantly raises the tax exempt threshold for home-owners. ${ }^{30}$ Given that home ownership is already high in Japan, this tax credit should be phased out or at least scaled down in its coverage.

\section{Improving the local tax system}

43. Broadening the personal income tax base would provide additional revenue for local governments, which receive a quarter of their revenue from taxes on personal income (the local inhabitant tax). Given the complicated local tax system, boosting local government revenues should focus on existing taxes, such as the local inhabitant tax, rather than on the introduction of new levies. As noted above, local governments have discretion, in principle, in setting the rates of some local taxes, including the local inhabitant tax, but rarely exercise this power due to several factors. First, local governments that cut rates below standard rates are not allowed to issue bonds to finance local public works without permission from the central or prefectural government. Second, as central government support is to some extent discretionary, local governments fear that cutting tax rates would result in lower grants from the central government. Such controls on local government autonomy, which are aimed at preventing irresponsible behaviour by local governments, should be removed in the process of local government reform. Instead, local governments should be subject to more financial market discipline. Finally, the key to raising more revenue from the local income tax is to broaden the tax base, which is set at the national level.

\section{Property and inheritance taxes}

44. Property tax as a share of GDP in Japan is higher than the OECD average, although lower than in some other major economies (Figure 20). OECD countries experienced a decline in the share of taxes on immovable property, from $8 \%$ to $6 \%$ of total tax revenue, over the past decade, in part as a result of voter resistance to such highly visible taxes and a failure to update property valuations in line with prices. Nevertheless, since revenues from property tax are relatively evenly distributed between regions (Figure 6) and the proceeds are relatively stable over the economic cycle, the dependence of local governments on property tax in Japan should be maintained and perhaps even increased further to offset the phasing out of local taxes on corporations. This could be accomplished by raising the assessed value of property from its

30. For a couple with two children, the mortgage tax credit raises the income tax threshold from 3.68 million yen to 9.3 million yen. 
current level of $70 \%$ of market value. Strengthening the role of property tax would also be effective in reducing inequality.

45. The burden of the inheritance tax has been reduced by an increase in the amount of deductions and the decline in land prices. Consequently, the tax is imposed on only $4 \%$ of persons at the time of death and accounted for $1.5 \%$ of tax revenue in FY 2005, compared to $5.5 \%$ and $2 \%$, respectively, a decade earlier. The number of inheritance tax brackets was reduced from nine to six rates and the top rate was reduced to $50 \%$. Strengthening the role of the inheritance tax, by reducing the basic deduction and raising the top tax rate, would help to promote equality. In FY 2003, the gift tax was reformed to bring it into line with the inheritance tax in an attempt to encourage transfers of assets from older to younger generations at an early stage, thus promoting the more effective use of assets. As a result, the total amount of tax is essentially the same whether parents give assets to their children or the assets are inherited after the parents' death.

Figure 20. International comparison of immovable property taxes

Per cent of GDP in 2005

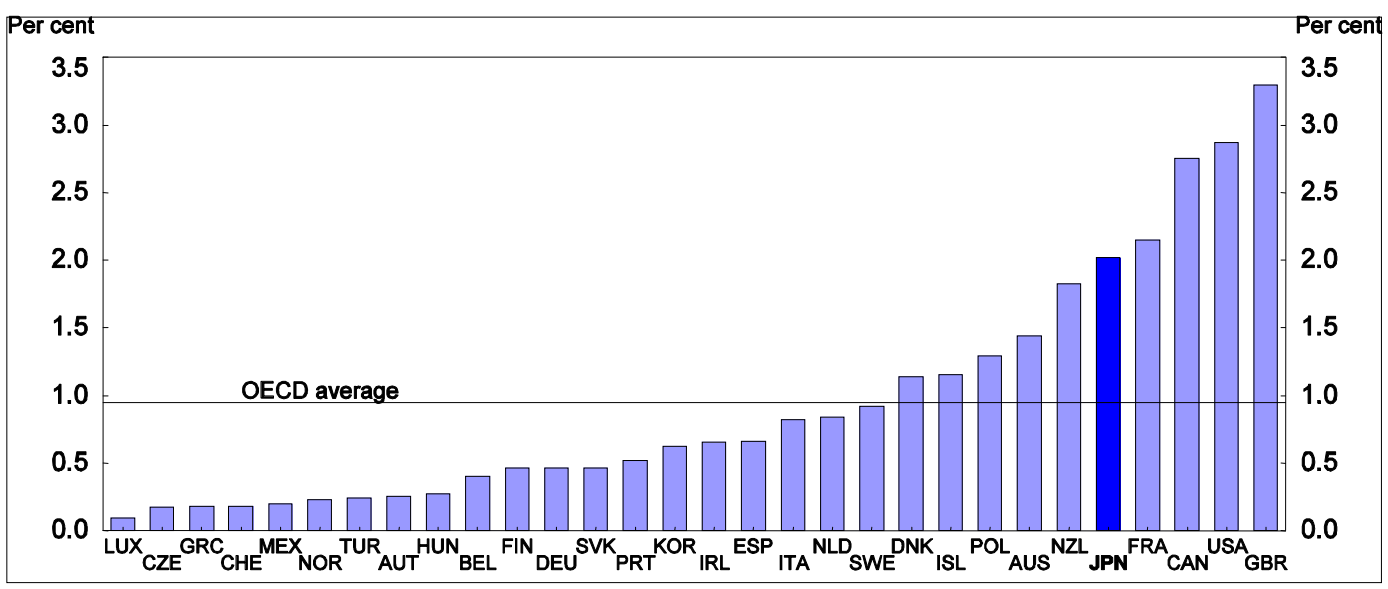

Source: OECD (2007c), Revenue Statistics 1965-2006, OECD, Paris (http://dx.doi.org/10.1787/366725334503).

\section{Directions for tax reform}

46. A comprehensive reform of Japan's tax system is essential to achieve fiscal sustainability. Indeed, as much as $6 \%$ of GDP in additional tax revenue is needed to stabilise the government debt to GDP ratio. In addition to fiscal objectives, tax reform should also aim at sustaining Japan's growth potential in the context of rapid ageing, limiting the upward trend in inequality and improving the local tax system. Specific recommendations for tax reform are summarised in Table 2.

47. The government plans to implement a fundamental tax reform. As a first step, the Tax Commission, a group of private-sector experts that was established by law in 1959, released its report on the direction for tax reform in November 2007. Many of the recommendations by the Tax Commission, which are summarised in Box 5, correspond to those proposed in this paper. However, there are a number of significant differences:

- The Tax Commission proposes a hike in the consumption tax rate to finance social welfare expenditures. The rise in social spending is part of the fiscal challenge facing Japan: the 
government projects that it will increase by $1 \%$ of GDP over the decade 2005 to 2015 . However, the need for additional revenue extends beyond social spending. From a long-term perspective, earmarking the rise in tax revenue could weaken efforts to control social spending, while limiting flexibility in expenditures.

- The Tax Commission favours expanding the pro-forma local government tax on enterprises. However, such taxes, which are based on the size of firms, are negative for growth and increase the risk of company failures during downturns. For this reason, a number of OECD countries have abolished or sharply reduced such taxes in recent years.

- The Tax Commission supports continued tax expenditures for activities, such as R\&D, that promote productivity. Such incentives should only exist if rigorous cost-benefit analysis reveals that they expand productivity-enhancing activities to levels that are socially optimal.

- To enhance the role of the personal income tax system in income redistribution, the Tax Commission recommends that a number of policies be examined; $i$ ) changes in tax brackets and rates, including the top rate of $50 \%$; ii) replacing personal deductions by tax credits; and iii) introducing an Earned Income Tax Credit, following an in-depth analysis of costs and benefits. Given that increasing the progressivity of tax rates risks discouraging the supply of labour and the acquisition of human capital, this paper favours achieving greater redistribution through an Earned Income Tax Credit that is financed through a broadening of the personal income tax system. 
Table 2. Summary of OECD recommendations

\begin{tabular}{|c|c|c|c|c|}
\hline & Raising revenue & Promoting growth & Reducing inequality & $\frac{\text { Increasing gains from }}{\text { decentralisation }}$ \\
\hline Consumption tax & $\begin{array}{l}\text { Raise the rate from the } \\
\text { current } 5 \% \text {, while } \\
\text { maintaining a unified } \\
\text { rate }\end{array}$ & $\begin{array}{l}\text { Raise the rate from the } \\
\text { current } 5 \% \text { to increase } \\
\text { reliance on indirect taxes } \\
\text { relative to direct taxes }\end{array}$ & $\begin{array}{l}\text { Raising the rate increases } \\
\text { the tax burden on pension } \\
\text { recipients, thus improving } \\
\text { inter-generational equity }\end{array}$ & $\begin{array}{l}\text { Raising the overall rate } \\
\text { would increase the local } \\
\text { consumption tax (set at a } 1 / 4 \\
\text { of the national rate) under } \\
\text { the current system }\end{array}$ \\
\hline Corporate income tax & $\begin{array}{l}\text { Broaden the tax base by } \\
\text { reducing tax } \\
\text { expenditures and cutting } \\
\text { generous deductions }\end{array}$ & $\begin{array}{l}\text { - Reduce the share of } \\
\text { corporate income tax in total } \\
\text { direct tax } \\
\text { - Lower the statutory tax rate } \\
\text { on corporations } \\
\text { - Phase out local taxes on } \\
\text { corporations }\end{array}$ & & $\begin{array}{l}\text { Phase out local taxes on } \\
\text { corporations, while relying } \\
\text { more on taxes on personal } \\
\text { income, consumption and } \\
\text { property }\end{array}$ \\
\hline Personal income tax & $\begin{array}{l}\text { - Broaden the tax base } \\
\text { - Increase compliance of } \\
\text { the self-employed by } \\
\text { improving enforcement, } \\
\text { in particular by } \\
\text { introducing taxpayer } \\
\text { identification numbers } \\
\text { and stronger penalties } \\
\text { for tax evasion }\end{array}$ & $\begin{array}{l}\text { - Increase the share of } \\
\text { personal income tax in total } \\
\text { direct tax } \\
\text { - } \quad \text { Remove features that distort } \\
\text { the allocation of investment } \\
\text { - Weaken disincentives for full- } \\
\text { time employment of } \\
\text { secondary earners in } \\
\text { households } \\
\text { - Reduce the preferential } \\
\text { treatment of the retirement } \\
\text { allowance } \\
\text { Consider reducing personal } \\
\text { income tax rates if the base } \\
\text { broadening of direct taxes } \\
\text { provides adequate revenue }\end{array}$ & $\begin{array}{l}\text { - Scale-down exemptions } \\
\text { that favour high-income } \\
\text { households } \\
\text { - Introduce an Earned } \\
\text { Income Tax Credit }\end{array}$ & $\begin{array}{l}\text { Broaden the base for the } \\
\text { local inhabitant tax, thereby } \\
\text { offsetting the phasing out of } \\
\text { local taxes on corporations }\end{array}$ \\
\hline $\begin{array}{l}\text { Property and inheritance } \\
\text { taxes }\end{array}$ & $\begin{array}{l}\text { Bring evaluations closer } \\
\text { into line with market } \\
\text { prices }\end{array}$ & & $\begin{array}{l}\text { - Bring evaluations closer } \\
\text { into line with market prices } \\
\text { - Strengthen the inheritance } \\
\text { tax by scaling back the } \\
\text { basic deductions. }\end{array}$ & $\begin{array}{l}\text { - Bring evaluations closer into } \\
\text { line with market prices }\end{array}$ \\
\hline
\end{tabular}


48. The main challenge from a political economy perspective is how to gain a consensus for a comprehensive tax reform that achieves the four objectives outlined in this paper. Fundamental tax reform is never easy, particularly when the reform must be revenue-enhancing as in Japan. In particular, the recommendation to lower corporate tax rates while raising the consumption tax rate and broadening the personal income tax base may be unpopular. It is important to point out that the corporate tax is borne not only by shareholders, but also by workers through reduced wages and possibly lower employment, suggesting that a cut in the corporate rate would boost household income and consumption. Indeed, a study of the United Kingdom found that workers bear about half of the corporate tax burden in the short run and all of it in the long run (Arulampalam, Devereux and Maffini, 2007).

49. Implementing a comprehensive tax reform requires clear communication of the plan and its objectives, based on transparent and well-articulated principles, so that taxpayers understand what the government is trying to achieve. This should include the following points:

- The government should demonstrate its commitment to improving the efficiency of spending before asking the public to pay higher taxes. Further efforts in this regard, such as the on-going cuts in public investment, the planned reduction in the government wage bill and the markettesting initiative (2008 OECD Economic Survey of Japan), would decrease public opposition to higher taxes.

- It is important to recognise that tax revenue in Japan is one of the lowest in the OECD area and well below the OECD average of $36 \%$ of GDP. If Japan, one of the most aged societies in the OECD area, wishes to maintain its social welfare system, higher tax revenues are unavoidable.

- The reform must be fair to the extent possible across different segments of the population. In particular, it is essential that the broadening of the tax base also includes the self-employed, thus avoiding an unfair burden on salaried workers.

- Nearly all OECD countries have launched substantial reforms of their tax systems in recent years, driven by the need to provide a fiscal environment that is more conducive to investment, risktaking and work incentives (OECD, 2004). Failure to do so in Japan would risk letting the country fall behind in an increasingly integrated and competitive world economy.

- The proposed tax reform should address emerging concerns about inequality, such as through the introduction of an Earned Income Tax Credit and a strengthening of inheritance and property taxes, as proposed in this paper. Such an approach would avoid increasing personal income tax rates, which tends to discourage human capital formation and labour supply. 
Box 5. A comparison of the OECD recommendations with those of the Tax Commission

OECD recommendations

- Boost the consumption tax rate from its relatively low level of $5 \%$ to raise additional revenue to achieve fiscal targets and thereby increase the share of indirect taxation.

- Maintain a single consumption tax rate to avoid the complications inherent in multiple-rate systems.

- Retain flexibility in allocating additional tax revenue.

- As the consumption tax rate is increased, maintain the share that is allocated to local governments, allowing them to reduce their reliance on more volatile taxes.

\section{Corporate taxation}

Personal income tax

- Reduce the statutory tax rate by phasing out local taxes on corporate income.

- Broaden the corporate tax base by reducing the number and size of tax expenditures, particularly those that target specific industries and regions, thereby improving the allocation of resources. Maintain incentives only if rigorous cost-benefit analysis demonstrates that they expand

- Increase the proportion of firms that pay the corporate income tax by modifying generous exemptions allowed in the tax code, while retaining loss carryover provisions, which encourage risk-taking

- Raise additional revenue by broadening the income tax
Tax Commission recommendations

- Hikes in the consumption tax rate, both at the national and local government levels, should be considered as an option to finance social welfare expenditures.

- Maintain a single tax rate, which is preferable for neutrality and simplicity. productivity-enhancing activities to socially optimal levels. base. The key priority is to reduce the deduction for wage income, while increasing the tax compliance of the selfemployed so as to enhance fairness between employees and the self-employed.

- Reform the deductions and allowances in the personal income and local inhabitant taxes that encourage secondary earners to limit their hours of work in order to keep income below certain thresholds.

- Reduce the preferential tax treatment of retirement allowances (the lump-sum payments) in order to promote labour mobility.
- A large number of the Commission's members insisted that the effective tax rate on corporations should be reduced in line with current international trends. measures to expand the tax base.

Preferential treatment of activities that promote productivity and sustainable growth, such as R\&D investment, should be continued.

- Local taxation of corporations based on the pro-forma approach should be expanded in light of the benefit principle.

- The wage income deduction should reflect actual expenses and working conditions.

- The deduction for self-employed business income should be examined more strictly, while considering the use of a lump-sum method of estimating the deduction.

- The spouse deduction should be examined in terms of its impact on the labour supply of spouses and the fairness of the double deduction (spouse deduction by the primary income earner and basic deduction by the secondary income earner).

- The retirement allowance system should be examined with the goal of reducing distortions in job choice and encouraging labour mobility.
Lower tax rates should be combined with consideration of 
- Address income inequality primarily through the introduction of an Earned Income Tax Credit, financed through broadening the base of the personal income tax system, while avoiding increasing its progressivity.

- Reduce exemptions, which tend to benefit high-income households, such as the mortgage deduction, to help reduce income inequality.

- Strengthen pension taxation by reducing the deduction on pension benefits and by taxing corporate-based pensions more strictly.

Local inhabitant tax

Financial income

\section{Property and inheritance} taxation
- The base of the local inhabitant tax should be broadened.

- Continue to move in the direction of a unified tax on financial income at a uniform rate to reduce distortions in the allocation of capital, while expanding the scope of loss offsets between various financial investments.

- Strengthen property taxation as a revenue source for local governments by bringing the assessment of property values used for tax purposes closer to market prices.

- Strengthen the role of the inheritance tax by reducing the basic deduction and raising the top tax rate to promote equality.
- The structure of rates and brackets should be examined from the perspective of enhancing the redistributive role of the tax system

- The level of the top rate $(50 \%)$, which has been reduced in past reforms, should be examined from the perspective of improving income distribution.

- Replacing income deductions by tax credits should be discussed as a way of strengthening the income redistribution function of the income tax system.

- Further discuss the introduction of an EITC with due considerations of its costs and benefits.

- Examine the merits of setting the deduction for dependents based on the age of the dependents and making it a tax credit to encourage fertility.

- The pension deduction for high-income persons should be examined as a way of promoting intra- and intergenerational fairness.

- The various deductions on the income part of the tax should be amended to allow the tax to follow the benefit principle.

- The amount of the per capita levy (fixed amount per household) should be increased.

- Abolish the temporary reduction of the tax on dividends and capital gains from listed securities that was introduced in FY 2003

- Expand possibilities for loss offsets in financial income.

- Pursue measures to equalise the tax burden across properties.

- To limit disparities in wealth, the role of the inheritance tax should be enhanced by scaling back the basic deduction, which was increased in the context of rising land prices, and raising the top rate. 
ECO/WKP(2008)58

\section{BIBLIOGRAPHY}

Arai, H. (2007), "Problems with estimation of income tax compliance rate based on SNA - focusing on the tax compliance rate of the self-employed", Reference No. 675, April 2007, the National Diet Library, Tokyo (in Japanese).

Arulampalam, W., M. Devereux and G. Maffini (2007), "The Incidence of Corporate Income Tax on Wages”, Oxford University Centre for Business Taxation Working Paper 07/07, Oxford.

Bassanini, A. and R. Duval (2006), "The determinants of unemployment across OECD countries: reassessing the role of policies and institutions", OECD Economic Studies, No. 42, OECD, Paris.

Bassanini, A., J. Rasmussen and S. Scarpetta (1999), "The Economic Effects of Employment-Conditional Income Support Schemes for the Low-Paid: An Illustration from a CGE Model Applied to Four OECD Countries", OECD Economics Department Working Paper No. 224, OECD, Paris.

Bassanini, A. and S. Scarpetta (2001), "The driving forces of economic growth: panel data evidence for the OECD countries", OECD Economic Studies, No. 33, OECD, Paris.

Baylor, M. (2005), "Estimating the excess burden of taxation through general equilibrium modeling", paper presented at the OECD Workshop on Tax and Growth, Paris, 30 March 2007.

Cabinet Office (2001), "Impact of income tax reforms in the 1990s", Policy Analysis Report No. 9, Tokyo (in Japanese).

Cabinet Office (2002a), Annual Report on the Japanese Economy and Public Finance (2001-02), Tokyo.

Cabinet Office (2002b), "The tax base and the tax burden of personal income tax", Policy Analysis Report No. 15, Tokyo (in Japanese).

Cabinet Office (2005), Annual Report on the Japanese Economy and Public Finance (2005-06), Tokyo.

Creedy, J. (2003), "The Excess Burden of Taxation and Why It (approximately) Quadruples when the Tax Rate Doubles", Treasury Working Paper No. 03/29, Wellington.

De Mooij, R.A. and S. Ederveen (2003), "Taxation and Foreign Direct Investment: A Synthesis of Empirical Research", International Tax and Public Finance, No. 10.

Diewert, E. and D. Lawrence (1994), "Measuring New Zealand's Productivity”, Treasury Working Paper No. 94/5, Wellington.

European Commission (2006), Structures of the Taxation Systems in the European Union, Brussels.

Förster, M. and M. Mira d'Ercole, (2005), "Income Distribution and Poverty in OECD Countries in the Second Half of the 1990s", OECD Social, Employment and Migration Working Paper No. 22, OECD, Paris. 


\section{ECO/WKP(2008)58}

Hajkova, D., G. Nicoletti, L. Vartia and K. Yoo (2006), "Taxation, Business Environment and FDI Location in OECD Countries", Economics Department Working Paper No. 502, OECD, Paris.

Ishi, H. (2001), The Japanese Tax System, Oxford: Oxford University Press.

Ishi, H. (2004), How will the tax burden change?, Chuo Koron Shinsha, Tokyo (in Japanese).

Ishi, H. (2006), "Moving towards a Dual Income Tax", Asia-Pacific Tax Bulletin, July/August 2006, IBFD, Washington.

Jaumotte, F. and N. Pain (2005), "Innovation in the business sector", OECD Economics Department Working Paper No. 459, OECD, Paris.

Leibfritz, W., J. Thornton and A. Bibbee (1997), "Taxation and Economic Performance", OECD Economics Department Working Paper No. 176, OECD, Paris.

Ministry of Economy, Trade, and Industry (2001), Study Group Report on Basic Taxation Issues for Economic Vitalisation, Tokyo (in Japanese).

Ministry of Finance (2007), Let's talk about taxes, Tokyo.

Ministry of Health, Labour and Welfare (1996, 2002 and 2007), General Research on the Condition of Part-time Workers, Tokyo (in Japanese).

Ministry of Health, Labour and Welfare (2005), Survey on Income Redistribution, Tokyo (in Japanese).

Ministry of Internal Affairs and Communications (2001), Survey on the Retirement Allowances of Private Companies, FY 2001, Tokyo (in Japanese).

Mintz, J. (2007), 2007 Tax Competitiveness Report, C.D. Howe Institute, Toronto, Canada.

Miyauchi, Y. ed. (2006), The Japanese Tax System Illustrated, FY 2006, Tokyo (in Japanese).

Morinobu, S. (2002), A study on the Japanese income tax base, Japan Tax Association, Tokyo (in Japanese).

Morinobu, S. (2003), Tax reform for the rebirth of Japan, Chuo Koron Shinsha, Tokyo (in Japanese).

Myles, G.D. (2007), "What do we know about the effects of taxes on growth", paper presented at the OECD Workshop on Tax and Growth, Paris, 30 March 2007.

Nippon Keidanren (2006), Recommendations concerning the FY 2007 tax reform, Tokyo (in Japanese).

OECD (1999), OECD Economic Survey of Japan, OECD, Paris.

OECD (2003), OECD Employment Outlook, OECD, Paris.

OECD (2004), "Recent Tax Policy Trends and Reforms in OECD Countries", OECD Tax Policy Studies No. 9, OECD, Paris.

OECD (2005), OECD Economic Survey of Japan, OECD, Paris. 
OECD (2006a), Consumption Tax Trends, OECD, Paris.

OECD (2006b), "Fundamental Reform of Personal Income Tax", OECD Tax Policy Studies No. 13, OECD, Paris.

OECD (2006c), Getting it Right: OECD Perspectives on Policy Change in Mexico, OECD, Paris.

OECD (2006d), OECD Economic Survey of Japan, OECD, Paris.

OECD (2006e), "Projecting OECD Health and Long-Term Care Expenditures: What are the Main Drivers?”, OECD Economics Department Working Paper No. 477, OECD, Paris.

OECD (2006f), Taxing Wages 2005/2006, OECD, Paris.

OECD (2007a), OECD Employment Outlook, OECD, Paris.

OECD (2007b), OECD Economic Survey of New Zealand, OECD, Paris.

OECD (2007c), Revenue Statistics, OECD, Paris (http://dx.doi.org/10.1787/366725334503).

OECD (2007d), Science, Technology and Industry Scoreboard, OECD, Paris.

OECD (2007e), Tax Database, OECD, Paris (www.oecd.org/ctp/taxdatabase).

OECD (2008), "Explaining Differences in Hours Worked Across OECD Countries", Going for Growth, OECD, Paris.

Ohta, H., H. Tsubouchi and T. Tsuji (2003), "Horizontal equity of income tax", Economic Assessment and Policy Analysis Discussion Paper DP/03-1, Cabinet Office, Tokyo (in Japanese).

Oliveira Martins, J., R. Boarini, H. Strauss, C. de la Maisonneuve and C. Saadi (2007), "The Policy Determinants of Investment in Tertiary Education”, OECD Economics Department Working Paper No. 576, OECD, Paris.

Tajika, E. and Yashio, H. (2007), "Addressing widening disparity through the tax system: utilising reimbursable tax credits", Zeikeitsushin 07.4, Tokyo (in Japanese).

Tax Commission (2002), "Policy guidance on the establishment of a desirable tax system", Tokyo (in Japanese).

Tax Commission (2003), “A sustainable tax system for Japan's ageing society”, Mid-term report by the Tax Commission, Tokyo (in Japanese).

Tax Commission (2004), "Basic view on the integration of financial income taxation", Sub-Committee on the Taxation of Financial Assets, Tokyo (in Japanese).

Tax Commission (2005), "Issues concerning personal income taxation", Sub-Committee on Fundamental Issues, Tokyo (in Japanese).

Tax Commission (2006a), "Main issues based on discussions so far", Sub-Committee on Fundamental Issues, Tokyo (in Japanese). 


\section{ECO/WKP(2008)58}

Tax Commission (2006b), "Towards further discussion on tax reform", a remark by Hiromitsu Ishi, Chair of the Commission, Tokyo (in Japanese).

Tax Commission (2007), "Basic view toward fundamental tax reform; a report to the inquiry from the prime minister", Tokyo (in Japanese).

Uemura, T. and S. Maekawa (2000), "Industrial Investment Behavior and Corporate Income Tax: Taxadjusted Q Approach Using Japanese Firm", Japan Center for Economic Research No. 41, Tokyo (in Japanese).

Yoo, K-Y. and A. de Serres (2004), "Tax treatment of private pension savings in OECD countries and the net tax cost per unit of contribution to tax-favoured schemes", OECD Economics Department Working Paper No. 406, OECD, Paris. 
ECO/WKP(2008)58

\section{WORKING PAPERS}

The full series of Economics Department Working Papers can be consulted at www.oecd.org/eco/Working_Papers/

649. What Drives the NAIRU? Evidence from a Panel of OECD Countries

(November 2008) Christian Gianella, Isabell Koske, Elena Rusticelli and Olivier Chatal

648. Short-term distributional effects of structural reforms: selected simulations in a DGSE framework (October 2008) Annabelle Mourougane and Lukas Vogel

647. Speed of adjustment to selected labour market and tax reforms (October 2008) Annabelle Mourougane, Lukas Vogel

646. The challenge of monetary policy in Turkey

(October 2008) Olcay Çulha, Ali Çulha and Rauf Gönenç

645. Improving cost-effectiveness in the health-care sector in Iceland (October 2008) Hannes Suppanz

644. Understanding Russian regions' economic performance during periods of decline and growth-an Extreme Bound Analysis approach

(October 2008) Rüdiger Ahrend

643. Do tax structures affect aggregate economic growth? Empirical evidence from a panel of OECD countries

(October 2008) Jens Arnold

642. Accounting for one-off operations when assessing underlying fiscal positions

(October 2008) Isabelle Joumard, Makoto Minegishi, Christophe André, Chantal Nicq and Robert Price

641. Do corporate taxes reduce productivity and investment at the firm level? Cross-country evidence from the Amadeus dataset

(October 2008) Cyrille Schwellnus and Jens Arnold

640. The challenge of rapidly improving transport infrastructure in Poland

(September 2008) Rafal Kierzenkowski

639. Bridging the housing gap in Poland

(September 2008), Rafal Kierzenkowski

638. Improving the business and investment climate in Indonesia (September 2008), Diego Moccero

637. Growth performance and policy challenges

(September 2008), Luiz de Mello

636. A taxonomy of instruments to reduce greenhouse gas emissions and their interactions (September 2008), Romain Duval 
$\mathrm{ECO} / \mathrm{WKP}(2008) 58$

635. Quantifying the effect of financial conditions on US activity (September 2008) Stéphanie Guichard and David Turner

634. Have long-term financial trends changed the transmission of monetary policy (September 2008), Stéphanie Guichard and David Turner

633. Raising education achievement and breaking the cycle of inequality in the United Kingdom (August 2008) Anne-Marie Brook

632. The euro changeover in the Slovak Republic: implications for inflation and interest rates (August 2008) Felix Hüfner and Isabell Koske

631. Tax reform for efficiency and fairness in Canada (August 2008) Alexandra Bibbee

630. Reforming the Polish Tax System to Improve its Efficiency (August 2008) Alain de Serres

629. Modernising Canada's Agriculture Policies (August 2008) Peter Jarrett and Shuji Kobayakawa

628. Recent trends and structural breaks in US and EU15 labour productivity growth (August 2008) Laure Turner and Hervé Boulhol

627. Health Status Determinants: Lifestyle, Enviroment, Health Care Resources and Efficiency (August 2008) Isabelle Joumard, Christophe André, Chantal Nicq and Olivier Chatal

626. Market Mechanisms in Public Service Provision (August 2008) Hansjörg Blöchliger

625. Improving human capital formation in India (July 2008) Sean M. Dougherty and Richard Herd

624. Labour regulation and employment dynamics at the state level in India (July 2008) Sean M. Dougherty

623. India's growth pattern and obstacles to higher growth (July 2008) Sean M. Dougherty, Richard. Herd, Thomas. Chalaux and Abdul. Erumban

622. Reaping the benefits of stronger competition in network industries in Germany (July 2008) Nicola Brandt

621. The Usefulness of Output Gaps for Policy Analysis (July 2008) Isabell Koske and Nigel Pain

620. Taxation and Economic Growth (July 2008) Assa Johansson, Christopher Heady, Jens Arnold, Bert Brys and Laura Vartia

619. Coping with labour shortages: How to bring outsiders back to the labour market (July 2008) Ekkehard Ernst 